\title{
BIODEGRADAÇÃO, EXTRAÇÃO E ANÁLISE DE GLIFOSATO EM DOIS TIPOS DE SOLOS
}

\author{
ADEMIR SÉRGIO FERREIRA DE ARAÚJO
}

Dissertação apresentada à Escola Superior de Agricultura "Luiz de Queiroz", Universidade de São Paulo, para obtenção do título de Mestre em Agronomia, Área de concentração: Microbiologia Agrícola.

\author{
PIRACICABA \\ Estado de São Paulo - Brasil \\ Abril - 2002
}




\title{
BIODEGRADAÇÃO, EXTRAÇÃO E ANÁLISE DE GLIFOSATO EM DOIS TIPOS DE SOLOS
}

\author{
ADEMIR SÉRGIO FERREIRA DE ARAÚJO \\ Engenheiro Agrônomo \\ Orientadora: Prof ${ }^{\mathrm{a}}$. Dr ${ }^{\mathrm{a}}$. REGINA TERESA ROSIM MONTEIRO
}

Dissertação apresentada à Escola Superior de Agricultura "Luiz de Queiroz", Universidade de São Paulo, para obtenção do título de Mestre em Agronomia, Área de concentração: Microbiologia Agrícola.

\author{
PIRACICABA \\ Estado de São Paulo - Brasil \\ Maio - 2002
}


Dados Internacionais de Catalogação na Publicação (CIP)

DIVISÃO DE BIBLIOTECA E DOCUMENTAÇÃO - ESALQ/USP

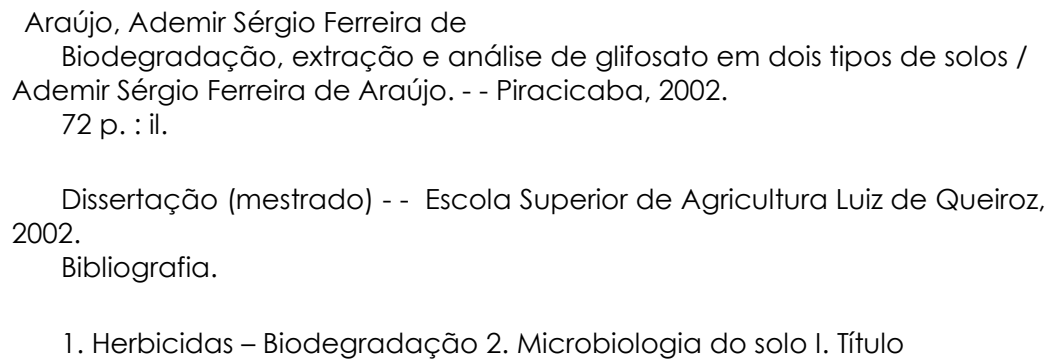

CDD 632.954

\section{"Permitida a cópia total ou parcial deste documento, desde que citada a fonte - $O$ autor"}


Aos meus pais Simão (In memoriam) e Zezita

Aos meus irmãos Fábio, Jailton, Robson, Shirley e Erika

Aos meus queridos sobrinhos

Aos meus familiares

DEDICO

À DEUS, que me fez compreender que devemos aceitar sempre a Sua vontade, e não a nossa.

À Ângela Célis

Por seu amor, carinho e companheirismo

OFEREÇO 


\section{AGRADECIMENTOS}

- À DEUS, por iluminar e guiar sempre a minha vida;

- À Profá . Dra. Regina Teresa Rosim Monteiro, pela orientação, amizade e ensinamentos oferecidos no decorrer do curso;

- À FAPESP pelo auxílio financeiro, através da concessão de bolsa de estudos, para realização do trabalho;

- À Dra . Rosângela Blota Abakerli, da EMBRAPA Meio Ambiente, pela cessão do equipamento de cromatografia líquida para realização das análises de glifosato e AMPA;

- Ao Prof. Dr. Ricardo Victoria, da ESALQ/USP e o Dr. Nélson Fonseca, do IAPAR/PR, pela autorização para a coleta dos solos utilizados neste trabalho;

- À Lourdes Silvestre de Souza, da EMBRAPA Meio Ambiente, pelo auxílio nas análises cromatográficas;

- Aos colegas do Laboratório de Ecotoxicologia Carlos Petri, Eduardo Armas, Guilherme Corrêa, Hélio Kamida, Priscila Dellamatrice pelo agradável convívio durante o curso;

- Aos amigos Andréa Mittelmam, Alessandra Fávero, Carolina Maranhão, Cláudio Tsutsumi, Estela Kaminagakura, Francisco Farias, Geraldo Arruda Filho, Gilmartin Santos e Maurisrael Rocha, pela boa amizade e auxílio em todos os momentos;

- Aos amigos Francisco Claúdio e Vanderlei Santos, pela amizade e convívio diário na "república do cuscuz";

- A todos que direta ou indiretamente contribuíram para este trabalho. 


\section{SUMÁRIO}

Página

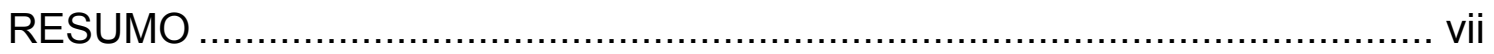

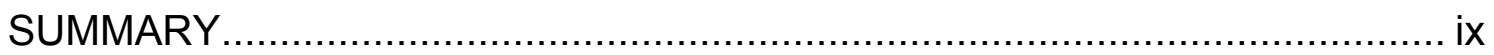

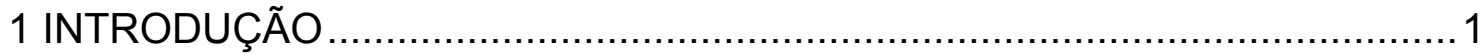

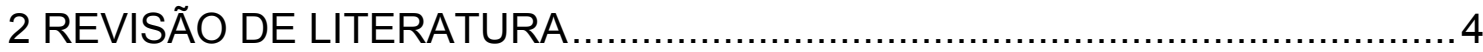

$2.1 \mathrm{~A}$ microbiota do solo e sua interação com pesticidas .................................. 4

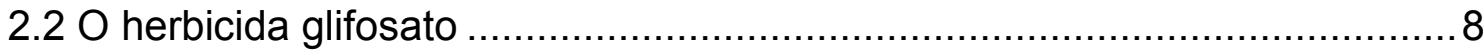

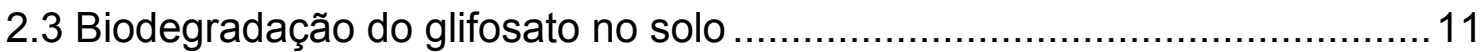

2.4 Extração e análise do glifosato do solo..................................................18

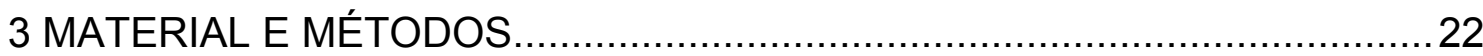

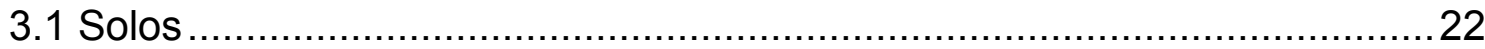

3.1.1 Determinação do peso seco e capacidade de campo ...........................24

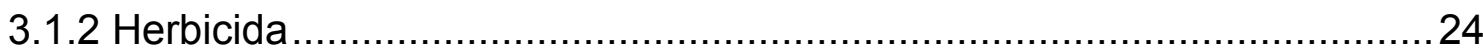

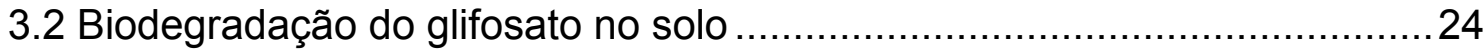

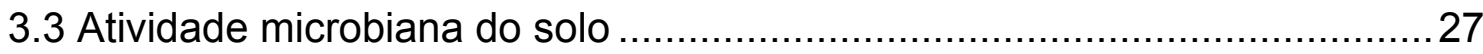

3.4 Quantificação de microrganismos do solo ............................................28

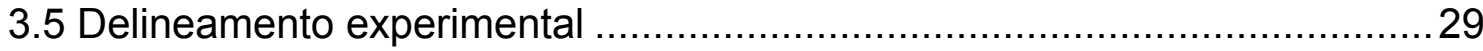

3.6 Extração e análise do glifosato e AMPA do solo.....................................29

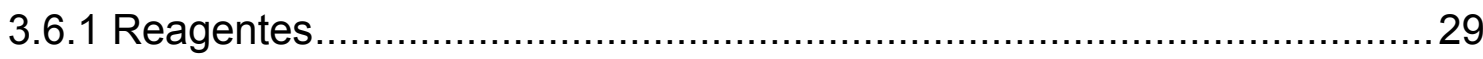

3.6.2 Preparação e condicionamento da coluna de troca catiônica ...................29

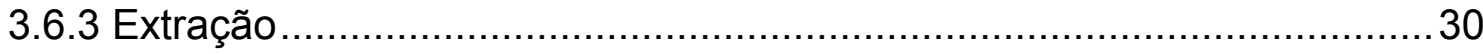

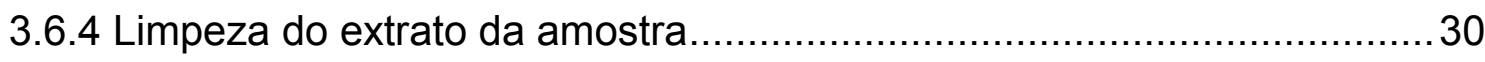

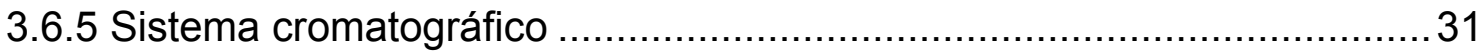

3.6.5.1 Cromatografia líquida de alta eficiência ............................................. 31 
3.6.5.2 Sistema de reação pós-coluna e derivatização.....................................31

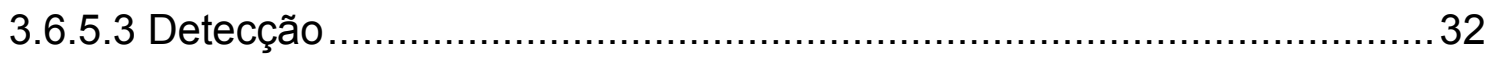

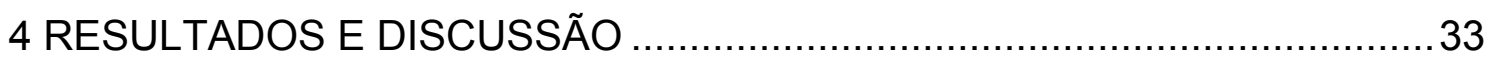

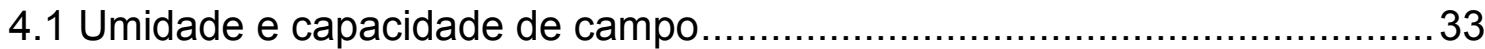

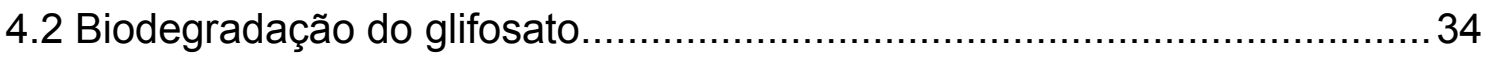

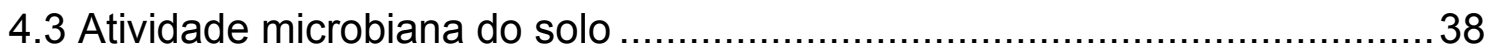

4.4 Quantificação de microrganismos do solo ........................................... 41

4.5 Extração e análise do glifosato do solo................................................... 45

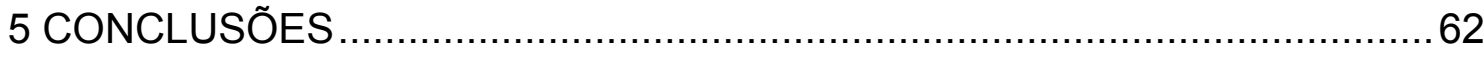

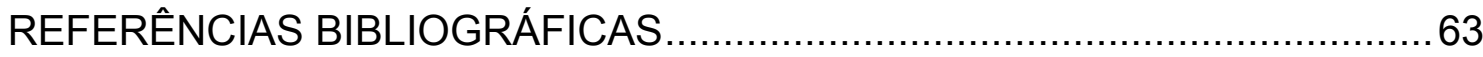




\title{
BIODEGRADAÇÃO, EXTRAÇÃO E ANÁLISE DE GLIFOSATO EM DOIS TIPOS DE SOLOS
}

\author{
Autor: Ademir Sérgio Ferreira de Araújo \\ Orientadora: Prof ${ }^{\mathrm{a}}$. Dr ${ }^{\mathrm{a}}$. Regina Teresa Rosim Monteiro
}

\section{RESUMO}

Este trabalho teve por objetivo avaliar a biodegradação do glifosato em amostras de solos, quantificando o grupo de microrganismos mais ativos durante este período, além de determinar um método de extração e análise para este herbicida. Foram utilizadas amostras de dois tipos de solos, um da Fazenda Experimental da ESALQ-USP, classificado como podzólico vermelhoamarelo (PV), e outro da Estação Experimental do IAPAR/PR, classificado como latossolo vermelho (LV), ambos com e sem histórico de aplicação de glifosato. O trabalho foi realizado no Laboratório de Ecotoxicologia do Centro de Energia Nuclear na Agricultura, da Universidade de São Paulo, utilizando o glifosato em sua fórmula técnica, na dosagem para condições de campo $(2,16$ $\mathrm{mg}$ i.a./kg de solo). A biodegradação do glifosato foi avaliada monitorando a evolução do $\mathrm{CO}_{2}$ pelos microrganismos durante um período de 32 dias. Foram também quantificados durante o período, os resíduos de glifosato e do seu metabólito ácido aminometil fosfônico (AMPA) através de extração seguida de análise por cromatografia liquida de alta eficiência (CLAE). Além disso, foi avaliada a atividade microbiana e o número de microrganismos presentes durante o período. Os resultados mostraram que o glifosato foi degradado pelos 
microrganismos do solo durante o período avaliado, com a formação do metabólito AMPA. O glifosato favoreceu um aumento na atividade microbiana das amostras dos solos que receberam aplicação do herbicida. Em relação ao número de microrganismos, os fungos e actinomicetos tiveram um aumento em população com a presença do glifosato, enquanto que as bactéria permaneceram em número constante durante o período de incubação. Os resíduos de glifosato e AMPA, extraídos com $\mathrm{NH}_{4} \mathrm{OH}$ e $\mathrm{KH}_{2} \mathrm{PO}_{4}$ e analisados por CLAE, foram detectados nas amostras avaliadas, mostrando que o método de extração utilizado foi eficiente, com recuperação acima de $70 \%$, para estes dois compostos. 


\title{
BIODEGRADATION, EXTRACTION AND ANALYSIS OF GLYPHOSATE IN TWO DIFFERENT SOIL TYPES
}

\author{
Author: Ademir Sérgio Ferreira de Araújo \\ Adviser: Prof ${ }^{a}$. Dr ${ }^{a}$. Regina Teresa Rosim Monteiro
}

\section{SUMMARY}

The aim of this work was to evaluate the biodegradation of glyphosate in soil samples, quantifying the group of more active microorganisms during this period, and also to establish an extraction and analysis methods for this herbicide. Two soils types were analysed, one from the ESALQ Experimental Station (USP), classified as typic hapludult (PV), and another from the IAPAR Experimental Station, classified as typic hapludox, with and without report of glyphosate application, in total of 4 samples. The work was carried out using the technical glyphosate in the doses for field conditions $(2,16 \mathrm{mg}$ a.i. $/ \mathrm{kg}$ of soil). The assessment of degradation was made using the $\mathrm{CO}_{2}$ evolution during a period of 32 days. The residues of glyphosate and metabolite aminomethyl phosphonic acid (AMPA) were quantified during the same period, through extraction and analysis by high-pressure liquid chromatography (HPLC). The soil microbial activity and the enumeration of microorganisms were evaluated during the same period. The results showed that glyphosate was degraded by the soil microorganisms, with the formation of the metabolite AMPA. The application of glyphosate provided an increase in the microbial activity of the soil 
samples. In relation to enumeration of fungi and actinomycetes had an increase in the population with the glyphosate application, while the number of bacteria remained constant through the whole experiment. The HPLC analyse of glyphosate and AMPA residues, extracted with $\mathrm{NH}_{4} \mathrm{OH}$ and $\mathrm{KH}_{2} \mathrm{PO}_{4}$, resulted in a recovery above $70 \%$ showing that the extraction method used was efficient for these two compounds. 


\section{INTRODUÇÃO}

O solo é um sistema vivo e heterogêneo composto de muitas associações microbianas. Estas associações são sensíveis a modificações físicas e químicas tais como alterações no modo de cultivo, adição de pesticidas ou de substâncias biologicamente ativas que podem afetar 0 equilíbrio microbiano.

Devido ao aumento da população e a crise de alimentos no mundo, o uso de pesticidas para o controle de ervas daninhas, doenças e pragas tornouse comum para o aumento da produção agrícola. Em função do uso intensivo de produtos químicos na agricultura moderna e a formação de grandes quantidades de resíduos, nos últimos anos tem havido uma maior preocupação em conhecer o comportamento e destino dos pesticidas nos diversos ecossistemas.

Os pesticidas são produtos utilizados na agricultura com finalidade de controle fitossanitário, aumento da produtividade e garantia da produção de alimentos para a humanidade que se encontra em contínuo crescimento. Muitos desses produtos têm seu efeito nocivo ao meio ambiente, devendo ser recomendado de maneira criteriosa a fim de reduzir o risco de impacto ambiental.

A necessidade de reduzir o impacto ambiental tem despertado o interesse científico para a biodegradação de pesticidas e compostos relacionados. Dentre as classes de pesticidas, os herbicidas tem sido os mais utilizados nas lavouras mundiais. O Brasil dispões de uma das maiores áreas 
agricultáveis do mundo, sendo um dos primeiros no "ranking" de vendas de pesticidas, onde os herbicidas correspondem quase a metade do volume total.

A ação dos microrganismos do solo sobre os herbicidas constitui-se em um mecanismo de maior importância, pois a degradação microbiológica, na maioria dos casos, contribui para a dissipação da molécula no ambiente.

O glifosato é um herbicida pós-emergente muito utilizado na agricultura e outras áreas não cultivadas, visando o controle de ervas daninhas anuais e perenes, sendo absorvido pelas plantas por difusão através da cutícula, entretanto não é metabolizado nas plantas, sendo sua principal degradação efetuada por microrganismos.

O termo biodegradação tem sido utilizado para a descrição de transformações de todos os tipos, incluindo aquelas que originam produtos menos tóxicos que o composto original, pela sua inativação, assim como aquelas responsáveis pela completa mineralização até $\mathrm{CO}_{2}, \mathrm{H}_{2} \mathrm{O}$ e outros ( Musumeci, 1992).

A completa degradação de um composto orgânico para $\mathrm{CO}_{2}$ (mineralização) e outros minerais constituintes é o resultado da atividade microbiana, tanto individual como em consórcio. Biodegradação de um pesticida por uma espécie pode ser ligada com reações adicionais por outros organismos eventualmente resultando na completa degradação do produto, sendo importante avaliar o que ocorre com os microrganismos do solo após sua aplicação, pois estes desempenham importante papel nos ciclos de nutrientes.

O estudo de degradação de um produto no solo pode ser analisado através de técnicas radiométricas ou cromatográficas, ambas acompanhadas pela formação de $\mathrm{CO}_{2}$ e aparecimento de metabólitos.

O glifosato se adsorve tanto às argilas como à matéria orgânica do solo, sendo sua recuperação normalmente baixa, dificultando, portanto, sua extração e posterior análise de resíduos em amostras ambientais.

A extração do glifosato e seu metabólito do solo vem sendo cada vez mais estudada objetivando determinar uma metodologia mais adequada e que 
tenha boa recuperação do herbicida aplicado, sendo encontradas diversas publicações estrangeiras, mas poucas brasileiras. Os métodos de extração, recuperação e análise de resíduos de glifosato do solo utilizam diversas substâncias extratoras que conseguem recuperação na faixa de 35\% a $100 \%$ do produto aplicado, dependendo da constituição do solo analisado. Os objetivos de trabalho foram: i) Avaliar a biodegradação de glifosato em amostras de solos com e sem histórico de aplicação deste herbicida, ii) Verificar o efeito de degradação acelerada do produto; iii) Determinar os grupos de microrganismos que estão mais ativos no solo e sua atividade microbiana no início e no final do período; iv) Determinar um método confiável de extração e análise de glifosato nas amostras de solos utilizadas, que apresentam diferentes texturas e histórico de aplicação em campo. 


\section{REVISÃO DE LITERATURA}

\subsection{A microbiota do solo e sua interação com pesticidas}

O solo é um sistema complexo, composto de cinco principais componentes: água, ar, material mineral, matéria orgânica e organismos, que interagem entre si, sendo que a variação de um deles pode ocasionar alterações nos demais (Alexander, 1977).

Diferentes efeitos antropogênicos, tais como adubação, manejo e outras práticas agronômicas podem modificar o ambiente do solo e consequentemente sua produtividade. Os insumos agrícolas aplicados pelo homem têm a finalidade de garantir a produção de alimentos para a humanidade, que se encontra em contínuo crescimento. Dentre esses insumos, os pesticidas são bastante utilizados.

Os pesticidas são compostos utilizados na agricultura para o controle de insetos, microrganismos e ervas daninhas, entre outros agentes que causam prejuízos ao homem. Embora os pesticidas possam ter um efeito benéfico sobre a produtividade agrícola, deve-se considerar o risco potencial desses compostos químicos no ambiente (Sanino et al., 1999).

Os microrganismos têm papel fundamental na manutenção da fertilidade do solo e decomposição da matéria orgânica, sendo importante considerar o efeito adverso dos pesticidas sobre a microbiota. O uso contínuo e indiscriminado 
de alguns pesticidas na agricultura tem ocasionado mudanças na população microbiana e atividade microbiana do solo (Taiwo \& Oso, 1997).

O pesticida pode atuar de duas formas sobre a microbiota do solo: de um lado ele pode influenciar os microrganismos responsáveis pela degradação e por outro lado pode atuar como substrato para o seu crescimento.

A degradação de pesticidas é conhecida como a transformação destes produtos em outros compostos menos tóxicos, $\mathrm{CO}_{2}$ e água. Esta degradação no solo pode ser realizada por via química ou biológica, ou a combinação das duas, entretanto a degradação microbiana é a via mais importante (Fomsgaard, 1997). Os microrganismos têm um papel fundamental no comportamento dos pesticidas no ambiente, pois possuem a capacidade de metabolizar estes compostos, através de suas enzimas, e transformá-los em energia e nutrientes para a sua sobrevivência.

A atividade microbiana é reconhecida como o principal fator que determina a taxa e a extensão em que os pesticidas são degradados no solo. Além disso a taxa de degradação de pesticidas é influenciada pela biomassa microbiana ativa e disponibilidade do composto para a biodegradação (Beigel et al., 1999). Segundo Suett et al. (1996) a maioria dos pesticidas podem ser degradados, inteiramente ou parcialmente, no ambiente por processos microbianos e vários trabalhos têm sido feitos durante os últimos anos para estabelecer os mecanismos biológicos dessa degradação.

Os pesticidas quando aplicados em quantidades recomendadas geralmente não têm efeitos adversos na população microbiana nativa do solo, podendo ocorrer um aumento desta população através da disponibilidade de nutrientes para os microrganismos, o que favorece a degradação destes compostos químicos. Os microrganismos, principalmente bactérias e fungos, têm sido descritos como os principais degradadores de pesticidas, e a introdução 
destes compostos no solo, podem servir de nutrientes, principalmente carbono, nitrogênio e fósforo (Monteiro, 2001).

Os microrganismos exibem estratégias para assimilação ou metabolismo do substrato que são o catabolismo e o cometabolismo. No catabolismo o substrato absorvido é quebrado em moléculas menores e vão gerar energia, consequentemente, a biomassa microbiana aumenta às custas do substrato, e este diminui consideravelmente. Por outro lado, no cometabolismo ocorre transformações de um substrato, entretanto, o crescimento microbiano exige a presença de um substrato secundário biodegradável como fonte de carbono e energia, desta forma transformam o composto sem dele retirar energia para seu desenvolvimento (Alexander, 1981).

A mineralização dos pesticidas é influenciada pelas propriedades quantitativas e qualitativas da microbiota do solo que provêem uma maior ou menor taxa de degradação, além da disponibilidade do composto para os microrganismos. Neste sentido, Lehr et al. (1996) avaliaram a mineralização do herbicida "isoproturon" em solos, relacionando com a atividade e biomassa microbiana. Os autores observaram que a biomassa e atividade microbiana correlacionaram-se com a mineralização do "ssoproturon" livre no solo, enquanto que no composto ligado não houve correlação entre a mineralização e os parâmetros microbianos.

Prado \& Airold (2000) avaliaram o efeito de doses do herbicida 2,4-D sobre a microbiota do solo, principalmente atividade microbiana, e observaram que o pesticida atua diretamente sobre os microrganismos. Inicialmente a população microbiana utiliza o herbicida como fonte de nutriente e em seguida com o aumento da quantidade aplicada ocorre um decréscimo na atividade microbiana. Anteriormente, Rath et al. (1998) avaliaram o efeito dos pesticidas 2,4-D, 2,4,5-T e HCH sobre a biomassa microbiana do solo e observaram que houve um incremento na biomassa de carbono após aplicação destes 
compostos. Outros trabalhos também estudaram o efeito de herbicidas sobre a microbiota do solo, especialmente a biodegradação (Souza, 1994) e número de microrganismos (Zablotowicz et al., 1998).

Os efeitos de outros pesticidas, principalmente fungicidas e inseticidas, sobre a microbiota do solo são objetos de vários trabalhos recentes. Bjornlund et al. (2000) avaliando a interação entre fungos, bactérias, protozoários e atividade microbiana sobre a degradação do fungicida "fenpropimorph" observaram que o produto afetou a atividade microbiana, avaliada pela hidrólise de diacetato de fluoresceína (FDA), até quatro meses após a aplicação. Os autores também observaram que não houve efeitos adversos no número de bactérias e protozoários no solo.

Em outro trabalho, o efeito do fungicida triazol sobre a atividade celulolítica dos microrganismos do solo foi avaliado por Munier-Lamy \& Borde (2000). Os autores observaram que a degradação da celulose e evolução do $\mathrm{CO}_{2}$ não foi afetada pela aplicação do composto nas dosagens recomendadas para condição de campo, entretanto houve um efeito adverso inicial quando o fungicida foi aplicado em altas dosagens.

A persistência do inseticida "fenamiphos" em solos esterilizados e não esterilizados foi avaliada por Megharaj et al. (1999), que observaram que $91 \%$ o inseticida foi rapidamente degradado em solos não-esterilizados, enquanto que nos solos esterilizados apenas $9 \%$ do composto aplicado sofreu degradação. Os resultados observados indicam que os microrganismos são os responsáveis pela degradação do inseticida no solo. Das \& Mukherjee (2000) avaliaram o efeitos de inseticidas sobre o desenvolvimento e crescimento de bactéria, actinomicetos e fungos, além da transformação e disponibilidade de nutrientes no solo. Os autores observaram que todos os inseticidas aumentaram a população microbiana e que houve um estímulo a mineralização e disponibilidade de carbono, nitrogênio e fósforo no solo. 
A adaptação da população microbiana a uma variedade de compostos químicos no ambiente, é a mensuração da sensibilidade ou insensibilidade aos produtos que poderiam ser tóxicos. O fenômeno de degradação acelerada do pesticida, induzida pela aplicação prévia do mesmo composto, foi explicada pela adaptação de um componente específico da comunidade microbiana, o que resulta numa atividade competitiva e subsequente proliferação desta população. Este fenômeno de adaptação pode ser resultado de interações entre o solo, pesticidas, microrganismos e condições ambientais (Somasundaram \& Coats, 1990).

A maioria dos estudos investigando os efeitos de pesticidas sobre os microrganismos do solo tem envolvido experimentos em laboratório, freqüentemente preocupados com os efeitos de aplicação de um simples composto. De qualquer modo, no campo, um ou mais pesticidas podem ser repetidamente aplicados no mesmo solo por vários anos, podendo deixar resíduos ou metabólitos, que podem exercer efeitos danosos sobre a biomassa microbiana (Hart \& Brookes, 1996).

Segundo Cheah et al. (1998), estudos de degradação no solo são essenciais para avaliação da persistência de pesticidas e seus metabólitos, inclusive dados sobre a taxa de mineralização são extremamente importantes pois permitem predizer os níveis prováveis de resíduo no solo e avaliar o risco potencial associado àsua exposição.

\subsection{0 herbicida glifosato}

Durante recentes anos o uso intensivo de herbicidas tem aumentado a preocupação ambiental, principalmente sobre sua poluição massiva do solo. Os herbicidas, dentre os pesticidas, são os produtos mais comercializados no mundo inteiro, face á necessidade de controle de ervas indesejáveis na agricultura. Neste 
sentido, o herbicida glifosato é muito promissor, devido sua eficiente capacidade de controlar ervas daninhas (Forlani et al., 1999).

O glifosato é um herbicida de largo espectro, não seletivo e de pósemergência, muito utilizado na agricultura e outras áreas não cultivadas para o controle de ervas daninhas anuais e perenes, introduzido nos anos 70 pela Monsanto. O herbicida é absorvido pelo tecido vivo e translocado, via floema, através da planta para as raízes e rizomas, e sua atuação nos vegetais inibe a produção de enzimas específicas, suspendendo a síntese de aminoácidos aromáticos. Em contato com o solo, o glifosato liga-se fortemente e dessa forma fica indisponível para absorção pelas plantas, perdendo sua ação herbicida.

O herbicida é degradado largamente pelos microrganismos do solo. $\mathrm{O}$ glifosato pertence a classe de compostos, conhecidos como ácidos fosfônicos, que contém uma ligação direta de carbono-fósforo (Kertesz et al., 1994). A ligação C-P é quimicamente estável, mas os microrganismos possuem habilidade enzimática de clivar a ligação e liberar fosfato inorgânico.

O glifosato pertence ao grupo químico das Glicinas, recebendo o nome químico de N-(Fosfonometil) Glicina, e sua fórmula estrutural é mostrada na Figura 1.

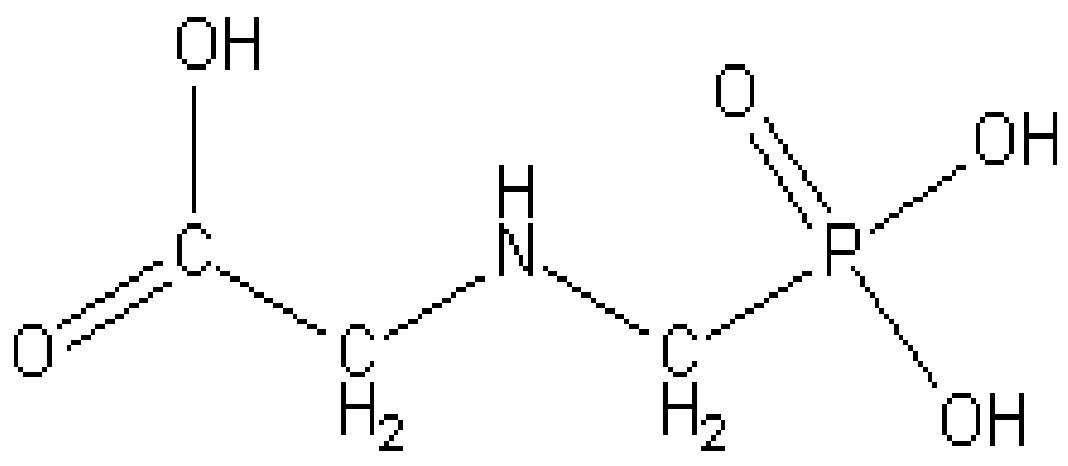

Figura 1 - Fórmula estrutural do glifosato (Knuuttila \& Knuuttila, 1979).

O sucesso comercial do glifosato como um herbicida extremamente efetivo e ambientalmente inofensivo tem estimulado extensivos estudos no solo 
sobre sua adsorção à partículas e degradação pelos microrganismos (KrzyskoLupicka \& Orlik, 1997 ; Forlani et al., 1999 ; Jonge \& Jonge, 1999 ).

O glifosato é utilizado para o controle de gramíneas e ervas de folhas largas anuais e perenes, sendo absorvido pelas plantas por difusão através da cutícula. A degradação microbiana leva a formação do seu principal metabólito, o ácido aminometilfosfônico (AMPA) e finalmente para dióxido de amônio e carbono. Aproximadamente $50 \%$ da molécula original é metabolizada em 28 dias, chegando a 90\% em 90 dias; é adsorvido pelos colóides da argila e húmus e a quantidade adsorvida é influenciada pela textura, teor de matéria orgânica e nível de fósforo, sendo pouco lixiviado no solo (Almeida, 1985).

Os estudos relacionados com a atividade do glifosato têm sido intensificados devido ao seu crescente uso no mundo, principalmente em relação àexposição do homem e do meio-ambiente ao herbicida. As propriedades físicoquímicas e toxicológicas do glifosato foram descritas em recente publicação (Dores \& De-Lamonica-Freire, 2001), como sendo:
a) constante de ionização ácida (Pka) - 3,8
b) classe toxicológica - III
c) pressão de vapor $(\mathrm{Pa})$ - desprezível
d) solubilidade em água - $900.000 \mathrm{mg} \cdot \mathrm{L}^{-1}$
e) coeficiente de partição octanol/água (Kow) $-\log 0,17 \times 10^{-2}$
f) coeficiente de adsorção (Koc) $-24.000 \mathrm{~cm}^{3} \cdot \mathrm{g}^{-1}$
g) meia-vida no solo $\left(\mathrm{DT}_{50}\right)-47$ dias
h) índice GUS - 2,81

Além destas propriedades, outras características principais do herbicida são (Monsanto, 1990): a) grupo químico - aminoácidos fosfanados; b) categoria iônica - herbicida anfótero; c) peso molecular - 228,2; d) densidade $1,18 \mathrm{~g} \cdot \mathrm{mL}^{-1}, \mathrm{a} 25^{\circ} \mathrm{C}$. 
Outros aspectos toxicológicos do glifosato foram analisados em recente revisão (Williams et al., 2000). Os autores abordaram aspectos relacionados a absorção oral e dermal, bioacumulação nos tecidos, genotoxicidade, danos ao DNA, entre outros, e concluíram que, dentro dos padrões estabelecidos, o herbicida não ofereceu risco àsaúde humana.

Em relação a sua acumulação nos solos agrícolas e seus possíveis danos ao ambiente, Bromilow et al. (1996) avaliaram a aplicação de pesticidas, incluindo o glifosato, por mais de 20 anos e observaram que não houve efeito deletério na produtividade das culturas nesse período. Outros trabalhos analisaram estudos relacionados a adsorção deste herbicida pela matéria orgânica, especialmente substâncias húmicas (Piccolo et al., 1996), o seu comportamento no solo (Eberbach, 1999) e na água (Zaranyka et al., 1993), além de aspectos relacionados a sua degradação pelos microrganismos (Souza, 1994).

Apesar do Glifosato não ser persistente no meio ambiente o conhecimento detalhado sobre sua biodegradação em solos brasileiros, bem como sobre os grupos de microrganismos capazes de degradar este composto é relativamente pequeno. Além disso, o aparecimento da soja transgênica, resistente ao glifosato, têm aumentado a preocupação ambiental devido, principalmente, àpossibilidade do uso maior do herbicida em campos cultivados, sendo necessários vários estudos sobre o comportamento do glifosato em solos de países tropicais.

\subsection{Biodegradação do glifosato no solo}

Os herbicidas são utilizados para o controle de plantas invasoras que competem com a cultura de interesse. Os efeitos adversos decorrentes da aplicação de herbicidas podem ocorrer na comunidade biótica do solo, 
ocasionando desequilíbrios nos processos bioquímicos, tais como decomposição da matéria orgânica e ciclagem de nutrientes (Ghini et al., 1997).

A ação dos herbicidas sobre o ambiente é influenciada pelas condições climáticas e características do solo, que passam a agir de forma combinada. Assim, a necessidade de se estudarem as diversas formas de interação desses produtos com o solo vem tornando-se imprescindível à compreensão dos possíveis caminhos tomados por esses produtos no meio.

Segundo Otto et al. (1997) a dinâmica dos herbicidas no solo cultivado é influenciada pelas características físico-químicas da molécula e variáveis pedoclimáticas, bem como a forma como esses solos são cultivados.

A persistência do herbicida no solo é resultado de processos de transformação (degradação da molécula, formação de metabólitos) e remoção (volatilização, escorrimento superficial, etc.), enquanto sua intensidade é fortemente influenciada pelas condições ambientais (temperatura, umidade, matéria orgânica, atividade microbiana) e pela tecnologia de aplicação (método usado, dose aplicada, formulação). (Pernin-Ganier et al., 1995).

Dentre os processos biológicos que determinam a persistência dos herbicidas no solo, a degradação microbiana constitui o de maior importância. Os microrganismos são os responsáveis pela degradação do glifosato no solo (Rueppel et al., 1977). A taxa de decomposição é inicialmente rápida, seguida por prolongada e lenta decomposição (Moshier \& Penner, 1978). Quando o produto entra em contato com a microbiota do solo, este é rapidamente inativado (Tortensson \& Aamisepp, 1977), podendo ser mineralizado, produzindo água, dióxido de carbono e fosfato (Forlani et al., 1999).

Segundo Liu et al. (1991), existem duas vias principais de degradação microbiana do glifosato: a primeira envolve a clivagem da molécula produzindo 0 ácido aminometilfosfônico (AMPA); a segunda é pela clivagem da ligação C-P do 
composto, por ação da enzima C-P liase, produzindo sarcosina. As principais vias de degradação do glifosato estão mostradas na Figura 2.

Sprankle et al. (1975) sugere rápida degradação microbiana, degradação química, adsorção ao solo, ou vários destes fatores combinados como explicação para o processo de desaparecimento do composto. A aplicação de um herbicida ao solo proporciona uma fonte imediata de carbono para os microrganismos, na fase inicial, de acordo com diferentes herbicidas, ocorre uma pequena degradação. Esta fase parece corresponder a um período de adaptação dos microrganismos, que produzem enzimas essenciais para degradar o novo substrato (Souza, 1994). Estas enzimas podem estar presentes dentro dos microrganismos, ou podem ser secretadas para a solução do solo, onde entram em contato, ou reagem com a molécula do herbicida. Em seguida, a população microbiana aumenta, acelerando o processo de decomposição dos substratos.
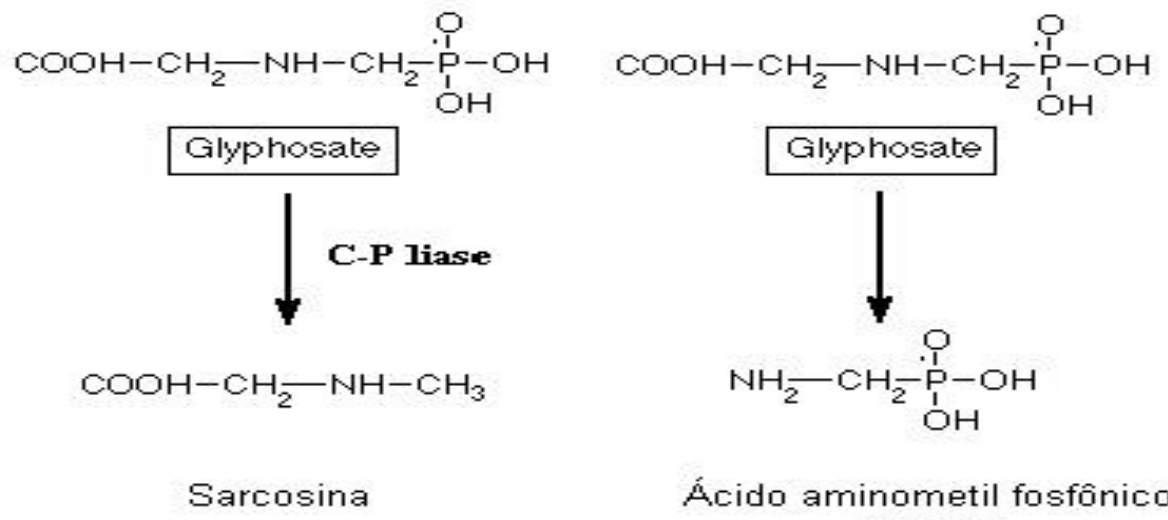

Ácido aminometil fosfônico (AMPA)

Figura 2 - Vias de degradação do glifosato (Dick \& Quinn, 1995).

Os herbicidas quando aplicados por vários anos tem sua degradação mais acelerada em relação ao produto aplicado pela primeira vez, pois os 
microrganismos degradadores estão mais adaptados ao composto e possuem enzimas específicas para metabolizar o composto. Robertson \& Alexander (1994) conduziram um estudo para avaliar a ocorrência de degradação acelerada de alguns herbicidas e observaram que o glifosato foi rapidamente e extensamente mineralizado após a sua primeira aplicação.

Segundo Monteiro (1996) o desaparecimento do composto químico parental e sua taxa de mineralização, comparando o solo com e sem aplicações prévias, são dois critérios para determinar se o fenômeno de degradação acelerada está ocorrendo.

Os microrganismos do solo tem sua população e atividade alteradas com a presença de herbicidas, devido ao aumento da fonte de carbono e outros nutrientes que favorecem o crescimento microbiano. Wardle \& Parkinson (1990b) avaliaram o efeito de várias concentrações de glifosato sobre a microbiota do solo e observaram que houve um crescimento temporário do número de bactérias, enquanto que a população de actinomicetos e fungos não foi afetada. Em outro trabalho Wardle \& Parkinson (1990a) estudaram o efeito de 2,4D, picloran e glifosato no solo e observaram que a atividade microbiana foi incrementada pela presença do herbicida glifosato.

Roslycky (1982) avaliando a influência de glifosato nos grupos de microrganismos do solo, observaram menos efeitos adversos do composto nos fungos, enquanto bactérias e actinomicetos tiveram suas atividades respiratórias prejudicadas. Em um trabalho recente, Busse et al. (2001), avaliaram a toxicidade de glifosato sobre a comunidade microbiana do solo e observaram que a atividade microbiana foi estimulada com a presença do composto, entretanto a respiração microbiana foi estimulada em altas doses do herbicida. Os autores concluíram que as taxas de aplicação de glifosato no campo mostraram pequeno ou nenhum efeito sobre a comunidade microbiana do solo. 
Os efeitos positivos ou negativos do herbicida na microbiota do solo podem ser resultados das dosagens de aplicação e formulação do glifosato. Stratton \& Stewart (1992) estudaram o efeito de glifosato, sobre a biomassa microbiana, número de microrganismos e a respiração do solo, e observaram houve um pequeno efeito estimulatório na biomassa microbiana em solos de floresta, enquanto que em relação ao número de microrganismos e a respiração não houve nenhum efeito positivo ou negativo. Os autores concluíram que o glifosato aplicado nas condições recomendadas não causa efeitos adversos na microbiota e respiração em solos de floresta. Recentemente, Armas (2002) avaliou o efeito do glifosato grau técnico e formulações sobre a microbiota do solo em áreas de várzea e observou que, em ambos os casos, os efeitos do herbicida sobre os microrganismos foram transitórios.

A degradação microbiana do herbicida glifosato é influenciada por diversos fatores, dentre eles, as características físicas e químicas do solo e da própria molécula que agem continuamente determinando sua magnitude (Souza et al., 1999b). A quantidade do herbicida disponível para os microrganismos do solo depende de vários fatores edáficos, incluindo nutrientes, $\mathrm{pH}$ do solo, temperatura e umidade (Haney et al., 2000).

A taxa de degradação do glifosato pode variar entre os diferentes tipos de solos que determinam a disponibilidade do composto para os microrganismos. Segundo Torstensson (1985), a variação da degradação pode ser devido ao nível de atividade microbiana do solo ou a adsorção do produto que regula a disponibilidade para a degradação no ambiente.

As condições físicas, químicas e biológicas do solo, além das variáveis climáticas e características do composto, podem favorecer sua maior ou menor persistência. Os solos tropicais possuem uma microbiota mais ativa que favorece uma degradação mais rápida do composto, diminuindo assim sua meia-vida no ambiente. A meia-vida do glifosato no ambiente pode variar consideravelmente, 
desde pouco menos que uma semana até anos, dependendo das características do solo e da sua atividade microbiana (Carlisle \& Trevors, 1988).

Os fatores que influenciam a persistência e comportamento de herbicidas no solo estão interrelacionados com a adsorção do pesticidas e com a disponibilidade do mesmo para biodegradação. Assim, a teoria estabelece que a degradação pode ocorrer na fração que permanece na fase não-adsorvida. Em recente estudo de análise compartamental sobre degradação de glifosato (fase adsorvida e fase não-adsorvida) mostrou-se que há uma rápida degradação no primeiro dia seguida de uma diminuição até o $40^{\mathrm{a}}$ dia, onde uma degradação máxima é alcançada (Eberbach, 1998). Segundo o autor os resultados são indicativos da influência de fatores do solo, particularmente, da adsorção, que restringe ao longo do tempo a disponibilidade do glifosato para degradação. É mostrado que a meia vida do glifosato é dependente das fases, sendo a da parte não-adsorvida de 6 a 9 dias e da parte adsorvida de 222 a 835 dias, dependendo dos solos avaliados. Assim é importante a consideração do $\mathrm{pH}$, níveis de ferro trocável e quantidade de argila.

O padrão de degradação da molécula do glifosato no solo é muito variável, dependendo do grupo de microrganismo presente e suas exigências nutricionais e sistemas enzimáticos. Obojska et al. (1999) trabalharam com isolados de Streptomicetos degradadores de fosforados e sugeriram que estes microrganismos são capazes de metabolizar o glifosato através do complexo enzimático C-P liase, utilizando o composto como fonte de carbono e fósforo.

Liu et al. (1991) avaliaram a degradação do glifosato por bactérias do gênero Rhizobium e observaram que o composto foi degradado através da clivagem da ligação carbono-fósforo, por ação da enzima C-P liase.

Souza et al. (1999b) trabalhando com degradação de glifosato e imazapir em solos brasileiros, submetidos a diferentes doses dos herbicidas, concluíram que a microbiota é capaz de utilizar o glifosato e o imazapir como 
fontes de carbono para seu crescimento. Anteriormente, Olson \& Lindwall (1991) avaliaram o efeito de 2,4-D e glifosato sobre a comunidade microbiana do solo em condições de campo e laboratório. Os resultados obtidos mostraram que o glifosato não apresentou efeitos adversos na biomassa microbiana, mineralização e nitrificação, em campo e laboratório.

A atividade microbiana do solo tem papel fundamental na degradação do glifosato, determinando sua persistência no ambiente. Os solos com uma microbiota mais ativa possibilita uma dissipação mais rápida do herbicida aplicado. Wiren-Lehr et al. (1997) estudando a mineralização do glifosato, observaram que a degradação do herbicida está relacionada com a biomassa e atividade microbiana, além disso ocorre uma maior mineralização quando o composto está em estado livre no solo. A adsorção do composto às partículas do solo dificulta a sua exposição ao ataque microbiano, aumentando sua persistência.

Segundo Bollag \& Liu (1990) e Rao et al. (1993) uma vez exposta æ̀ comunidades microbianas do solo, as moléculas estariam sujeitas a cinco possibilidades de transformação ou inativação: a) biodegradação em que a molécula poderia servir como substrato de crescimento e energia; b) cometabolismo, em que o herbicida é transformado por reações metabólicas, mas não serviria como fonte de energia aos microrganismos; c) polimerização ou conjugação, em que a molécula, ou seu intermediário, seria conjugado com outros compostos presentes naturalmente no solo; d) acumulação, em que a molécula seria incorporada e acumulada dentro do microrganismo; e) efeitos secundários da atividade microbiana, em que o herbicida é transformado, por causa de mudanças no $\mathrm{pH}$, reações de redox e produtos reativos, entre outros, proporcionado pelos microrganismos.

$\mathrm{Na}$ maioria dos casos, a transformação da molécula, durante sua exposição a um microrganismo, ou toda a microbiota do solo, não ocorre apenas 
por um único mecanismo. A molécula pode ser metabolizada por vários caminhos no ambiente resultando diferentes produtos oriundos da mesma molécula (Souza, 1998).

\subsection{Extração e análise do glifosato do solo}

A maioria dos trabalhos sobre o glifosato detalham a atividade do herbicida nas plantas, contudo a literatura sobre o seu comportamento no solo é pouco extensa (Torstenson, 1985). O glifosato, por sua característica química, possui a capacidade de se ligar fortemente ao solo, modificando sua atuação e seu comportamento. Morillo et al. (2000), relatam que o glifosato está ligado aos constituintes do solo através do radical ácido fosfônico por um mecanismo similar ao fosfato inorgânico. A adsorção do composto é influenciada pelas propriedades do solo (CTC, pH, etc.), do herbicida (Caráter iônico, pKa, etc.) e das variáveis do meio (temperatura, umidade, etc) (Pignatello, 1989).

O glifosato possui grupos funcionais amina, carboxila e fosforados que podem simultaneamente se ligarem a íons metálicos formando quelatos, além disso a sua adsorção por óxidos de Fe acarreta rápida inativação de sua função herbicida em contato com o solo (McBride, 1994). O composto compete com o orto-fosfato por sítios disponíveis de sorção, confirmando a importante função do grupo fosfonato na sorção do glifosato, além da energia iônica e o cátion dominante que também têm influencia na sorção do produto ao solo (Jonge \& Jonge, 1999).

O glifosato pode se complexar com a fração solúvel de substâncias húmicas de forma tão importante quanto sua adsorção com argilas e poderia nesta forma ser transportado através do solo (Torstensson, 1985).

Os estudos sofre a dissipação do herbicida no solo têm sido realizados no sentido de compreender a relação entre a atividade microbiana e sua função 
na dinâmica deste composto, não se preocupando com a determinação dos resíduos presentes após o ataque microbiano. Eberbach (1999), reporta que na literatura pertinente a decomposição do glifosato no solo, poucos trabalhos estavam disponíveis em relação a extração e análise de glifosato e seus metabólitos e que foram usados para monitorar a degradação após extensos períodos de tempo.

Devido ao caráter complexo das interações do glifosato com diversos componentes do solo, os métodos de extração descritos têm se mostrados complexos e fortemente dependentes do tipo e características dos solos. O glifosato demonstra uma forte ligação através do ácido fosfônico às argilas minerais, existindo uma dependência com o teor de ferro, caolinita, $\mathrm{pH}$ e matéria orgânica do solo (Sprankle et al., 1975), e vários procedimentos tem sido testados para sua análise. Milles \& Moye (1988) desenvolveram um método de determinação do glifosato em vários tipos de solo, utilizando fosfato de potássio monobásico e hidróxido de potássio, e obtiveram recuperação de 35\% a 100\% do herbicida aplicado.

A composição do solo é um fator importante para determinar a baixa ou alta recuperação do glifosato. Roy \& Konar (1989) conseguiram recuperação variando entre $45 \%$ e $70 \%$ de acordo com o tipo de solo, por meio de extração com ácido fosfórico.

Spann \& Hargreaves (1994), estudaram um método analítico para extrair e determinar o glifosato do solo com médios a altos teores de argila, demonstrando uma recuperação de cerca de $80 \%$ a $90 \%$ do glifosato aplicado. Em um outro trabalho, Alferness \& Iwata (1994) conseguiram recuperar de $70 \%$ a $90 \%$ do herbicida aplicado utilizando $\mathrm{NH}_{4} \mathrm{OH}$ e $\mathrm{KH}_{2} \mathrm{PO}_{4}$ como extrator em diferentes solos.

Kataoka et al. (1996) obtiveram recuperação de $90 \%$ a $100 \%$ do glifosato aplicado em um solo argilo-arenoso utilizando solução de hidróxido de 
sódio com um método bastante simples e rápido. Outro estudo sobre a recuperação do glifosato e seu principal metabólito AMPA do solo foi realizado por Sancho et al. (1996), através da extração com hidróxido de potássio e análise por cromatografia líquida. Os resultados mostraram recuperação entre $88 \%$ e $109 \%$ de glifosato e $73 \%$ e $103 \%$ de AMPA.

Borjesson \& Tortensson (2000) desenvolveram um método para determinação de glifosato e AMPA em solo e água, através da extração com hidróxido de sódio e encontraram recuperação média de 103\% e 96\% em água, e $78 \%$ e $75 \%$ em solo para glifosato e AMPA, respectivamente.

Em virtude poucas informações sobre o comportamento do glifosato em países tropicais, Souza et al. (1999a) desenvolveram um trabalho sobre mobilidade do glifosato e imazapir em solos brasileiros. Para isto utilizaram hidróxido de potássio como extrator do glifosato do solo com análise das amostras por polarografia, e obtiveram recuperação de $76 \%$ a $78 \%$ do herbicida aplicado. Segundo os autores o glifosato foi adsorvido pelos solos analisados, devido suas características físico-químicas, apresentando uma baixa lixiviação.

A maioria dos trabalhos sobre degradação de glifosato tem sido realizados usando-se o composto radiomarcado, onde o comportamento do herbicida tem sido avaliado através de medidas do ${ }^{14} \mathrm{CO}_{2}$ evoluído dos solos tratados. Nos casos de estudos com o glifosato "frio", são usados os métodos cromatográficos para avaliar o desaparecimento do composto e formação de metabólitos (degradação). Os métodos cromatográficos são os mais comumentes utilizados para avaliar compostos em amostras biológicas e de solo (Eberbach \& Douglas, 1991).

Muitos métodos de análises para glifosato e seu metabólito AMPA foram descritos, inclusive cromatografia gasosa (Moye \& Deyrup, 1986), cromatografia de camada delgada (Young et al., 1977) e HPLC - High Perfomance Liquid Chromatography (Span \& Hergreaves, 1994). Todos esses 
métodos porém requerem passos de derivatizações manuais ou procedimentos de limpeza das amostras complexos, tornado demorado o processo. Para as análises por HPLC, a ausência de cromofóros torna necessário que o composto seja derivatizado com reagentes antes da coluna (pré-coluna) (Milles \& Moye, 1983) ou depois da coluna (pós-coluna) (Span \& Hargreaves, 1994).

A derivatização pós-coluna, comparada com o procedimento de précoluna, possui uma seletividade mais alta e limites de detecção abaixo de ppb, sendo importante para análises de matrizes mais complexas, tais como amostras de solo e alimentos (Glass, 1983).

As dificuldades em estabelecer métodos simples para extração e determinação desses compostos a níveis de resíduos são principalmente devido ̀̀ suas propriedades: altamente solúveis em água, insolúveis em solventes orgânicos e comportamento complexante (Stalikas \& Konidari, 2001)

Neste sentido, a utilização de um método adequado de extração e análise de glifosato e AMPA deve levar em consideração o tipo e a composição do solo, além do tipo e concentração do solvente, para proporcionar maior recuperação do herbicida aplicado e, obtenção de resultados confiáveis e seguros na análise de seus resíduos. 


\section{MATERIAL E MÉTODOS}

O trabalho foi realizado no Laboratório de Ecotoxicologia, da Divisão de Funcionamento de Ecossistemas Tropicais do Centro de Energia Nuclear na Agricultura - CENA/USP, Piracicaba, SP. As análises cromatográficas foram realizadas no Laboratório de Resíduos de Pesticidas da EMBRAPA Meio Ambiente, Jaguariúna, SP.

\subsection{Solo}

As amostras de solo foram coletadas de uma área cultivada com pêssego, na Fazenda Experimental da ESALQ/USP, situada no município de Piracicaba/SP, sendo uma amostra de uma subárea sem histórico aplicação (PV1) e outra com histórico de 06 anos de aplicação de glifosato (PV2). O solo foi classificado como sendo podzólico vermelho-amarelo, textura argilosa.

Foram coletadas, simultaneamente e com os mesmos procedimentos, outras amostras de solo de uma área, da Fazenda Experimental do IAPAR, situada no município de Londrina/PR, sendo uma amostra de uma subárea sem histórico de aplicação (PV3), cultivada com banana, e outra com histórico de 11 anos de aplicação de glifosato PV4), cultivado com soja no sistema plantio direto. O solo foi classificado como sendo latossolo vermelho, textura muito argilosa. Em cada subárea foram coletadas subamostras de solo, inteiramente ao acaso na área, em 10 pontos na profundidade de $0-10 \mathrm{~cm}$ e que formaram a amostra composta. 
$\mathrm{Na}$ Tabela 1, estão apresentados os dados das análises físicoquímicas, das amostras dos solos, realizadas pelo Departamento de Solos e Nutrição de Plantas, da Escola Superior de Agricultura Luiz de Queiroz, da Universidade de São Paulo.

Tabela 1. Composição físico-química das amostras dos solos coletadas na camada de $0-10 \mathrm{~cm}$.

\begin{tabular}{lcccc}
\hline Determinação & PV1 & PV2 & LV3 & LV4 \\
\hline $\mathrm{pH} \mathrm{em} \mathrm{H}_{2} \mathrm{O}(1: 2,5)$ & 5,9 & 5,7 & 5,6 & 5,2 \\
$\mathrm{pH}$ em KCl $(1: 2,5)$ & 5,3 & 5,3 & 5,0 & 4,2 \\
Matéria Orgânica $\left({\left.\mathrm{g} \cdot \mathrm{kg}^{-1}\right)}^{-1}\right.$ & 23 & 23 & 26 & 20 \\
$\mathrm{H}+\mathrm{Al}\left(\mathrm{mmolc}_{\mathrm{kg}}{ }^{-1}\right)$ & 18 & 27 & 32 & 56 \\
$\mathrm{~T}\left(\mathrm{mmolc} . \mathrm{kg}^{-1}\right)$ & 92,0 & 88,3 & 118,2 & 92,1 \\
$\mathrm{~V}(\%)$ & 80 & 69 & 73 & 39 \\
Areia (\%) & 49 & 41 & 03 & 01 \\
Silte (\%) & 9 & 13 & 11 & 08 \\
Argila (\%) & 42 & 46 & 86 & 91 \\
Classe de textura & arg. & arg. & m. arg. & m. arg.
\end{tabular}

As amostras dos solos foram deixadas à temperatura ambiente, sendo em seguida peneirados em malhas de $2 \mathrm{~mm}$, e então determinou-se o peso seco e a capacidade de campo. O restante das amostras foi acondicionada em sacos plásticos fechados frouxamente com barbante e papel (para possibilitar 
"respiro" para os microrganismos) e mantidos à temperatura de $4^{\circ} \mathrm{C}$, para posterior análises.

\subsubsection{Determinação do peso seco e capacidade de campo.}

Amostras de $10 \mathrm{~g}$ de solo foram levadas para secar em estufa à temperatura de $105^{\circ} \mathrm{C}$ por 24 horas, em três repetições. A umidade foi determinada, em porcentagem, pela diferença dos pesos dos solos antes e após a secagem em estufa.

$\mathrm{Na}$ determinação da capacidade de campo, foram colocados $150 \mathrm{~g}$ de solo em um béquer de $500 \mathrm{~mL}$ de capacidade e adicionou-se gota a gota $2 \mathrm{~mL}$ de água destilada, com auxílio de uma pipeta, por 40 segundos. O torrão formado foi colocado em uma placa de Petri e levada à estufa para secar à temperatura de $105^{\circ} \mathrm{C}$ por 24 horas. A capacidade de campo foi calculada pelo peso seco do solo que absorveu os $2 \mathrm{~mL}$ de água adicionados.

\subsubsection{Herbicida}

O herbicida utilizado foi o glifosato, aplicado em sua formula técnica (99\% de pureza, gentilmente cedido pela Monsanto), na dosagem recomendada para condições de campo $\left(6,0\right.$ L.ha $\left.^{-1}\right)$, sendo calculado a quantidade aplicada utilizando $360 \mathrm{~g}$ i.a./litro. A dosagem final aplicada nas amostras de solo foi de 2,16 kg i.a./ha, convertidos para 2,16 mg i.a./kg de solo.

\subsection{Biodegradação de glifosato no solo}

A metodologia utilizada foi a descrita por Bartha \& Pramer (1965), que quantifica o dióxido de carbono desprendido na respiração microbiana do solo.

O herbicida glifosato foi aplicado na dosagem de 2,16 mg. $\mathrm{kg}^{-1}$ de solo, uniformemente nas amostras de solos contidas em sacos plásticos que foram 
agitados para homogeneização. Foram utilizados $75 \mathrm{~g}$ (peso seco) de cada amostra de solo que foram adicionados em Erlenmeyers de $250 \mathrm{~mL}$ de capacidade que tem fundido lateralmente um tubo de $50 \mathrm{~mL}$, com fundo arredondado. A umidade do solo foi ajustada para $75 \%$ da capacidade de campo. Após adição do solo, cada frasco foi fechado com uma rolha de borracha, sobre a qual foi montado um filtro de cal sodada, munido de uma torneira. O tubo foi fechado com tampa de borracha perfurada com uma agulha de $15 \mathrm{~cm}$ de comprimento e com abertura superior fechada com rolha de vidro (Figura 3).

A unidade foi acrescida com $10 \mathrm{~mL}$ de hidróxido de potássio $(\mathrm{KOH})$ 0,2 N, por injeção, removendo a tampa do filtro e a tampa de vidro da abertura e adicionando $\mathrm{KOH}$ através da abertura no tubo. A torneira é fechada, a rolha de vidro e tampa do filtro recolocadas em suas posições iniciais (frasco hermeticamente fechado).

O dióxido de carbono desprendido e coletado no álcali, foi amostrado periodicamente, retirando-se os $10 \mathrm{~mL}$ de $\mathrm{KOH}$, com auxílio de seringa, e adicionando novamente $10 \mathrm{~mL}$ de $\mathrm{KOH}$ livre de $\mathrm{CO}_{2}$. A amostra de $\mathrm{KOH}$ retiradas foi adicionada em erlenmeyer de $125 \mathrm{~mL}$, contendo $1,0 \mathrm{~mL}$ de $\mathrm{BaCl}_{2}$ para precipitar todo $\circ \mathrm{CO}_{2}$ e 3 gotas de fenolftaleína como indicador, sendo titulados com $\mathrm{HCl} \mathrm{0,1} \mathrm{N}$ até a viragem, anotando-se o volume gasto.

O mesmo procedimento descrito acima foi utilizado para testemunhas sem adição de solo (branco), para determinar a quantidade de $\mathrm{CO}_{2}$ desprendido devido a atividade microbiana.

A quantificação do $\mathrm{CO}_{2}$ desprendido foi realizado nos períodos de 2 , 4, 8, 16, 24 e 32 dias após a incubação do solo, sendo calculado pela seguinte formula (IBAMA, 1990):

$\mu \mathrm{g} \mathrm{C}^{-\mathrm{CO}_{2}}=[(\mathrm{mL} \mathrm{HCl}$ gasto branco $)-(\mathrm{mL} \mathrm{HCl}$ gasto tratamento $)] \times \mathrm{N} \times 22$ onde:

$\mathrm{N}$ : normalidade do $\mathrm{HCl}$, determinada a cada coleta por titulação com $\mathrm{NaOH} 0,1 \mathrm{~N}$ 


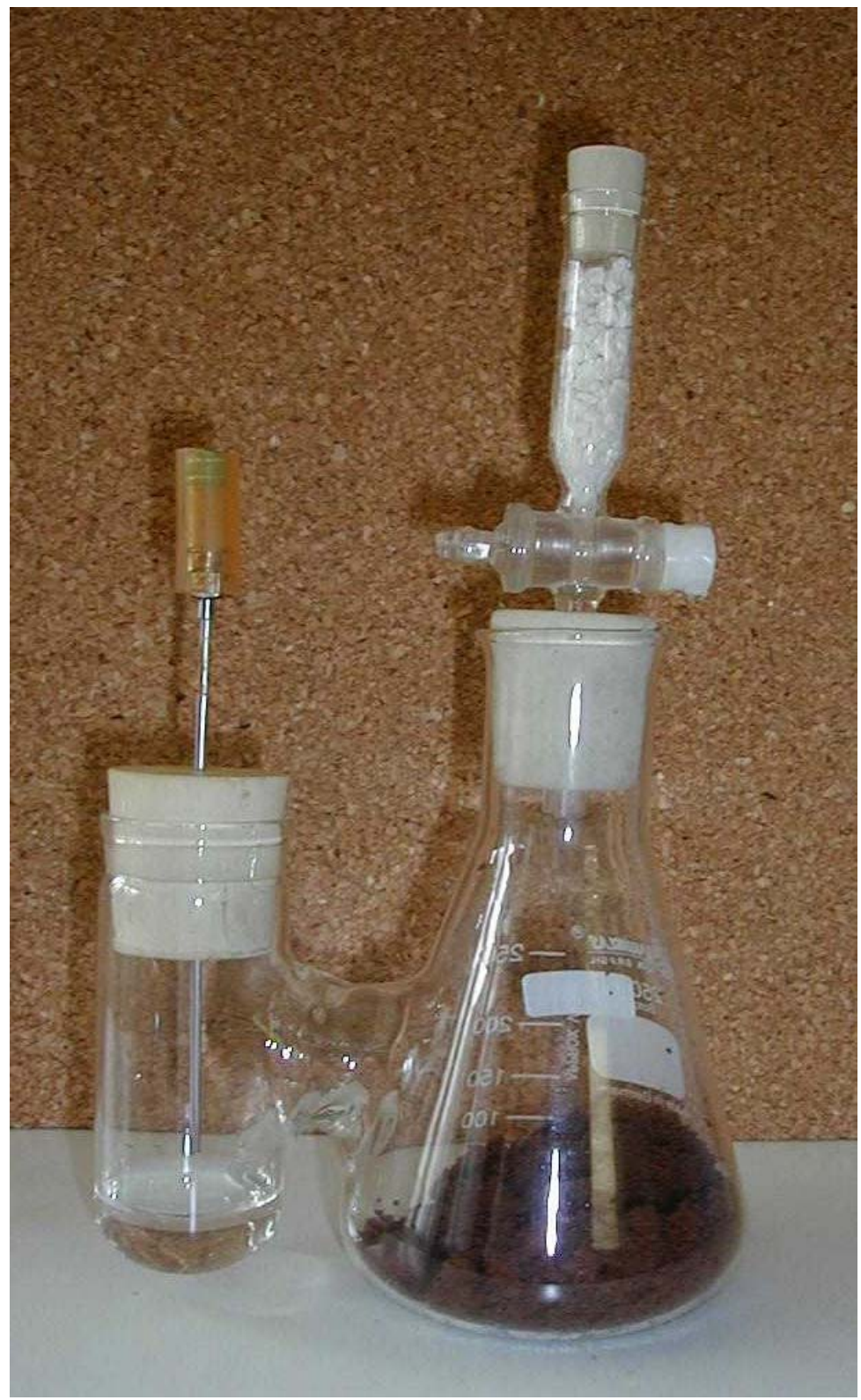

Figura 3 - Frasco respirométrico utilizado no experimento de biodegradação (Bartha \& Pramer, 1965). 


\subsection{Atividade microbiana do solo}

A atividade microbiana foi avaliada de acordo com a técnica de hidrólise de diacetato de fluoresceína (FDA) (Schnürer \& Rosswall, 1982). Amostras de $5 \mathrm{~g}$ (peso seco) de cada amostra de solo, em cinco repetições e umidade ajustada para $75 \%$ da capacidade de campo, foram distribuídas em Erlenmeyers de $125 \mathrm{~mL}$ de capacidade, adicionando-se, posteriormente, $20 \mathrm{~mL}$ de tampão fosfato de sódio ( $8,7 \mathrm{~g}$ de $\mathrm{K}_{2} \mathrm{HPO}_{4}+1,3 \mathrm{~g}$ de $\mathrm{KH}_{2} \mathrm{PO}_{4}$ dissolvido em $1000 \mathrm{~mL}$ de água, $\mathrm{pH}$ 7,6) e $200 \mu \mathrm{L}$ de uma solução de FDA, na concentração de $2 \mathrm{mg}$ de FDA. $\mathrm{mL}^{-1}$ em acetona, fechando-se os mesmos com folha de alumínio.

Os Erlenmeyers foram incubados sob agitação, a $150 \mathrm{rpm} \mathrm{e}$ temperatura de $24^{\circ} \mathrm{C}$, por $20 \mathrm{~min}$. Após esse período, a reação foi paralisada com $20 \mathrm{~mL}$ de acetona, e o sobrenadante foi filtrado em papel de filtro Whatman n.1. As soluções foram avaliadas em espectrofotômetro (comprimento de onda de $490 \mathrm{~nm}$ ). A atividade microbiana foi determinada pela quantidade de FDA hidrolisado, com auxílio das equações das curvas-padrão obtidas de cada um dos solos analisados.

Para determinação da curva-padrão, procedeu-se como descrito acima, utilizando concentrações de 0, 100, 200, 300 e $400 \mu \mathrm{g}$ de FDA, obtidas com a adição de $0,50,100,150$ e $200 \mu \mathrm{L}$ de FDA, respectivamente. O FDA foi hidrolisado por calor $\left(100^{\circ} \mathrm{C}\right)$ em banho-maria, por $5 \mathrm{~min}$, com a adição de $5 \mathrm{~mL}$ de tampão fosfato de sódio. Após hidrólise, misturou-se as soluções com o solo e adicionou-se $15 \mathrm{~mL}$ de tampão fosfato de sódio, agitando por 20 minutos. Procedeu-se a leitura em espectrofotômetro (comprimento de onda de $490 \mathrm{~nm}$ ).

A atividade microbiana foi avaliada no tempo 0 dias e aos 32 dias de incubação do solo 


\subsection{Quantificação de microrganismos do solo}

$\mathrm{Na}$ determinação da comunidade microbiana presente no solo foi utilizado a técnica do número mais provável (NMP) em plaqueamento por gotas descrita por Jahnel et al. (1999), fazendo-se diluição em série à extinção.

Foram pesados $10 \mathrm{~g}$ de cada amostra de solo e adicionados em frascos contendo $90 \mathrm{~mL}$ de solução salina à $0,85 \%$. Os frascos foram agitados por 10 minutos a $150 \mathrm{rpm}$ em agitador circulante. A partir deste frasco, foram preparadas as diluições, para bactérias a partir de $10^{-3}$ a $10^{-7}$ e para actinomicetos e fungos a partir de $10^{-2}$ a $10^{-6}$. Em seguida foi tomada alíquota de $0,1 \mathrm{~mL}$, com auxílio de micropipeta adicionando em tubos contendo $0,9 \mathrm{~mL}$ de meio de cultura com ágar a $1 \%$ e mantida em banho-maria a $45^{\circ} \mathrm{C}$. Os meios de cultura utilizados foram o ágar-nutriente ( $5 \mathrm{~g}$ de peptona, $3 \mathrm{~g}$ de extrato de carne, $10 \mathrm{~g}$ de $\mathrm{NaCl}, 10 \mathrm{~g}$ de ágar, dissolvidos em 1 litro de água deionizada) para bactérias; o meio ágar-nutriente $(5 \mathrm{~g}$ de glicose, $10 \mathrm{~g}$ de peptona, $10 \mathrm{~g}$ de ágar, dissolvidos em 1 litro de água deionizada) para actinomicetos; e o meio de Martin ( $1 \mathrm{~g} \mathrm{KH}_{2} \mathrm{PO}_{4}, 1 \mathrm{~g}$ de $\mathrm{MgSO}_{4} .7 \mathrm{H}_{2} \mathrm{O}, 5 \mathrm{~g}$ de peptona, $10 \mathrm{~g}$ de dextrose, $0,033 \mathrm{~g}$ de rosa bengala, $0,05 \mathrm{~g}$ de estreptomicina, $10 \mathrm{~g}$ de ágar, dissolvidos 1 litro de água deionizada) para fungos.

O plaqueamento foi feito com gotas do meio de cultura em alíquotas de $0,040 \mathrm{~mL} /$ gotas, com auxílio de micropipeta, utilizando 5 gotas de cada diluição colocadas, uma ao lado da outra, em placas de Petri estéreis. Em seguida as placas foram vedadas com Parafilm ${ }^{\mathrm{TM}} \mathrm{e}$ incubadas durante 48 horas à $28^{\circ} \mathrm{C}$.

Após este período foram feitas observações da presença de unidades formadoras de colônias (UFC). O NMP foi determinado utilizando uma tabela de ocorrência estatística. O número de microrganismos foi avaliado no início da incubação do solo e no final do período de 32 dias. 


\subsection{Delineamento experimental}

O delineamento experimental utilizado foi o inteiramente casualizado com 4 tratamentos: 1- sem histórico e sem aplicação de glifosato, 2- sem histórico e com aplicação de glifosato, 3- com histórico e sem aplicação de glifosato, 4- com histórico e com aplicação de glifosato; em 3 repetições retiradas de cada amostra de solo. Para comparação de médias foi utilizado o teste de Tukey ao nível de $5 \%$.

\subsection{Extração e análise de glifosato e AMPA do solo}

\subsubsection{Reagentes}

Os reagentes utilizados são todos padrões analíticos (PA) e estão listados abaixo.

Hidróxido de amônia (Merck ${ }^{\mathrm{TM}}$ ), cloreto de sódio (Merck ${ }^{\mathrm{TM}}, 99,9 \%$ pureza), cloreto férrico (J.T. Baker ${ }^{T M}$ ), dihidrogênio fosfato de potássio (Aldrich $^{\mathrm{TM}}$,grau HPLC), hipoclorito de cálcio ( sinth $^{\mathrm{TM}}, 65 \%$ de pureza), ácido bórico ( Riedel-de-Haen ${ }^{\mathrm{TM}}$ ), 2-mercaptoetanol ( Aldrich $^{\mathrm{TM}}$ ), Brig 35 (Aldrich ${ }^{\mathrm{TM}}$ ), metanol $\left(\right.$ Merck $\left.^{\mathrm{TM}}\right)$, ácido clorídrico concentrado (Merck ${ }^{\mathrm{TM}}$ ), ácido fosfórico (Merck $^{\mathrm{TM}}, 85 \%$ de pureza), padrão analítico de glifosato (Monsanto ${ }^{\mathrm{TM}}, 99 \%$ ), padrão analítico de AMPA (Monsanto ${ }^{\mathrm{TM}}, 99 \%$ ), resina de troca catiônica Dowex 50W-X8, 100-200 mesh forma hidrogênio (Aldrich ${ }^{\mathrm{TM}}$ ).

\subsubsection{Preparação e condicionamento de coluna de troca catiônica}

A resina de troca catiônica Dowex-50W ( $20 \mathrm{~g}$ ) foi dissolvida em ácido clorídrico $0,01 \mathrm{M}$ até formar uma pasta. Em seguida foi introduzida numa coluna cromatográfica (20 cm de comprimento, $1,9 \mathrm{~cm}$ de diâmetro interno), e 
condicionada com ácido clorídrico $0,01 \mathrm{M}(80 \mathrm{~mL})$ a uma taxa de fluxo de 2,5 $\mathrm{mL} \cdot \mathrm{min}^{-1}$.

\subsubsection{Extração}

Amostras de solo (10 g), retiradas do experimento de incubação aos $0,8,16$ e 32 dias ( 3 repetições), foram colocadas em tubos de centrifuga de 75 $\mathrm{mL}$ e adicionados $\mathrm{NH}_{4} \mathrm{OH} 0,25 \mathrm{M}+\mathrm{KH}_{2} \mathrm{PO}_{4}$ 0,1 M (40 mL), sendo em seguida agitadas por 90 min usando um shaker horizontal ( $120 \mathrm{rpm}$ ) e centrifugadas por à $2000 \mathrm{rpm}$ por $20 \mathrm{~min}$. O sobrenadante foi transferido para outro tubo de centrífuga e ajustado o $\mathrm{pH}$ para $2,0 \mathrm{com} \mathrm{HCl} 5 \mathrm{M}$ e centrifugado novamente a $2500 \mathrm{rpm}$ por $10 \mathrm{~min}$. O sobrenadante foi filtrado em papel filtro GF/A e transferido para balão volumétrico de fundo redondo de $300 \mathrm{~mL}$. Repetiu-se o procedimento acima para o resíduo sólido restante no tubo de centrifuga. $\mathrm{O}$ volume foi diminuído para aproximadamente $5 \mathrm{~mL}$ em concentrador rotatório à vácuo (temperatura de $60^{\circ} \mathrm{C}$ ).

$\mathrm{O}$ extrato de solo foi ajustado para $\mathrm{pH}$ 1,8-2,0 com $\mathrm{NH}_{4} \mathrm{OH}$ concentrado e transferido para um tubo de centrifuga, com lavagens de ácido clorídrico $0,01 \mathrm{M}$, e centrifugado $4000 \mathrm{rpm}$ por $10 \mathrm{~min}$.

\subsubsection{Limpeza do extrato utilizando a coluna de troca catiônica}

O extrato do solo foi transferido para uma coluna contendo resina de troca catiônica, condicionada anteriormente, com um fluxo regulado de 2,5 $\mathrm{mL} \cdot \mathrm{min}^{-1}$. Em seguida foram feitas lavagens seqüenciais com porções de $5 \mathrm{~mL}$ de acido clorídrico $0,01 \mathrm{M}$ até um volume total de $20 \mathrm{~mL}$, descartando o eluído. O glifosato foi eluído da coluna usando ácido clorídrico 0,1 M (100 mL) sendo coletado em balão de $500 \mathrm{~mL}$. O extrato limpo foi então evaporado à secura em evaporador rotatório à vácuo ( temperatura de $60^{\circ} \mathrm{C}$ ). $\mathrm{O}$ resíduo foi redissolvido com $5 \mathrm{~mL}$ de fase móvel $\left(0,005 \mathrm{M}\right.$ de $\mathrm{KH}_{2} \mathrm{PO}_{4}, 4 \%$ metanol, $\mathrm{pH} 2,1$, ajustado 
com ácido fosfórico) e colocado em balão volumétrico de $5 \mathrm{~mL}$. O extrato final foi filtrado em membrana Millipore de $0,45 \mu \mathrm{m}$ utilizando uma seringa com adaptador e o glifosato e AMPA foram determinados por cromatografia líquida de alta eficiência (CLAE).

\subsubsection{Sistema cromatográfico}

\subsubsection{Cromatografia líquida de alta eficiência}

O equipamento consiste num modelo Shimadzu (LC 10AD) com uma coluna analítica para glifosato ( 5 um, $300 \mathrm{~mm}$ x 4,6 mm de diâmetro interno, resina iônica, forma $\mathrm{K}^{+}$, suporte sulfonatado divinil benzeno-stireno copolímero) mantida à temperatura de $50^{\circ} \mathrm{C}$. A taxa de fluxo da fase móvel foi de 0,5 $\mathrm{mL}$. $\mathrm{min}^{-1}$. O volume injetado da amostra foi de $100 \mu \mathrm{L}$.

\subsubsection{Sistema de reação pós-coluna e derivatização}

A determinação do glifosato envolveu uma reação de oxidação póscoluna para amina primaria à $38^{\circ} \mathrm{C}$, seguida de derivatização com OPA-MERC em um espiral de aço inoxidável ( $2 \mathrm{~m} \times 0,2 \mathrm{~mm}$ de diâmetro interno). $\mathrm{O}$ reagente oxidante consistiu de hipoclorito de cálcio contendo $0,02 \mathrm{~g}$ de $\mathrm{Ca}\left(\mathrm{ClO}_{2}\right), 1,36 \mathrm{~g}$ de $\mathrm{KH}_{2} \mathrm{PO}_{4}$, e $11,6 \mathrm{~g}$ de cloreto de sódio dissolvido em 1 litro de água deionizada.

O reagente OPA-MERC consistiu de 1,0 mL de 2-mercaptoetanol, 400 mg de fluoraldeído (97\%), $25 \mathrm{~g}$ de ácido bórico dissolvido em 1 litro de água deionizada.

Duas bombas peristálticas foram usadas para obter um fluxo de 0,3 $\mathrm{mL} \cdot \mathrm{min}^{-1}$ para o reagente oxidante e o OPA-MERC. 


\subsubsection{Detecção}

A detecção foi realizada usando um detector de fluorescência com comprimento de onda de excitação de $350 \mathrm{~nm}$ e emissão de $440 \mathrm{~nm}$ e um integrador. Os tempos de retenção para o glifosato e AMPA foram 22 e 44 min, respectivamente. 


\section{RESULTADOS E DISCUSSÃO}

\subsection{Umidade e capacidade de campo}

Os resultados obtidos para umidade e capacidade de campo dos solos analisados estão apresentados na Tabela 2. Observa-se que as amostras de pódzolicos vermelho-amarelo (PV1 e PV2) possuem capacidade de campo inferiores em relação as amostras de Latossolo vermelho-amarelo (LV3 e LV4). A textura dos solos coletados no IAPAR, classificada como muito argilosa, favorece uma maior capacidade de campo para este tipo de solo.

Tabela 2. Umidade e capacidade de campo das amostras dos solos PV1, PV2, LV3 e LV4.

\begin{tabular}{ccc}
\hline Solo & $\begin{array}{r}\text { Umidade de Campo } \\
(\%)\end{array}$ & $\begin{array}{c}\text { Capacidade de Campo } \\
(\mathrm{mL} / 100 \mathrm{~g} \text { solo })\end{array}$ \\
\hline PV1 & 9,96 & 15,39 \\
PV2 & 9,33 & 14,72 \\
LV3 & 20,6 & 39,13 \\
LV4 & 20,6 & 37,03 \\
\hline
\end{tabular}




\subsection{Biodegradação do glifosato}

Os resultados da degradação do glifosato obtidos através da evolução de $\mathrm{CO}_{2}$ pelos microrganismos no período de 32 dias estão apresentados nas Figuras 4 e 5, para os solos PV e LV, respectivamente.

Observa-se que nos tratamentos em que foi aplicado o glifosato a quantidade de $\mathrm{CO}_{2}$ desprendida aos 32 dias foi de 0,42 e $0,49 \mu \mathrm{g} / \mathrm{g}$, para os solos PV1 e PV2, e de 0,46 e 0,49 $\mu \mathrm{g} / \mathrm{g}$, para os solos LV3 e LV4, respectivamente. Estes resultados foram maiores que os encontrados para os tratamentos controle, que apresentaram quantidades de $\mathrm{CO}_{2}$ desprendido aos 32 dias de 0,32 e 0,39 $\mu \mathrm{g} / \mathrm{g}$, para o solos PV1 e PV2, e de 0,40 e 0,38 $\mu \mathrm{g} / \mathrm{g}$, para o solo LV3 e LV4, respectivamente. Entretanto não foram observadas diferenças estatísticas entre todos os tratamentos, na quantidade de $\mathrm{CO}_{2}$ acumulado durante o período de incubação. A evolução do $\mathrm{CO}_{2}$ do solo tem sido utilizada como índice de atividade microbiana, da biomassa ativa e, ainda, do metabolismo do carbono lábil do solo (Souza et al., 1999b) Estes resultados sugerem que a microbiota do solo é capaz de utilizar o glifosato como fonte de carbono para o seu metabolismo, proporcionando um incremento na respiração microbiana, medida pelo desprendimento de $\mathrm{CO}_{2}$ destes solos.

Segundo Rueppel et al. (1977), o glifosato é um composto rapidamente degradado na presença dos microrganismos do solo. A aplicação do herbicida estimula a microbiota do solo, favorecendo a decomposição do composto, e dependendo da concentração aplicada e da composição da molécula a sua persistência será maior ou menor. O glifosato pode causar estimulação ou inibição da capacidade respiratória do solo, dependendo da concentração usada (Grossbard \& Atkinson, 1985). Wardle \& Parkinson (1990a) indicam que a produção de $\mathrm{CO}_{2}$ está relacionada com a decomposição direta do herbicida no solo.

Os resultados obtidos pela respiração microbiana mostram que ocorreu uma degradação rápida do glifosato aplicado nos solos na fase inicial 
de incubação até o oitavo dia, a partir daí houve uma estabilização na quantidade de $\mathrm{CO}_{2}$ desprendida pelos microrganismos. Souza (1994) estudando a atividade do glifosato em solos observou que o herbicida foi rapidamente degradado até o décimo dia de incubação e a partir daí houve uma estabilização na respiração microbiana. Os microrganismos conseguem utilizar apenas a fração que está disponível para degradação e sendo o glifosato fortemente adsorvido pelos componentes do solo, a sua degradação é mais rápida logo após a aplicação. Sprankle et al. (1975) reporta que o glifosato sofre uma decomposição inicial rápida seguida de uma baixa e contínua degradação. Segundo os autores isto é devido à adsorção do glifosato à argila e matéria orgânica do solo que impedem a utilização posterior do herbicida pelos microrganismos. Nomura \& Hilton (1977) estudando a degradação do glifosato em vários solos do Hawai observaram que $\circ \mathrm{CO}_{2}$ desprendido foi maior nos primeiros dias decrescendo com o tempo.

A degradação do glifosato está diretamente relacionada a quebra da ligação C-P do composto, através da clivagem dessa ligação pelos microrganismos, que a partir daí utilizam o composto como fonte de carbono e fósforo. A degradação de compostos fosforados, como o glifosato, é devida principalmente à ação da atividade da C-P liase, que está presente na maioria dos microrganismos (Lerbs et al., 1990; Obojska et al., 1999). 


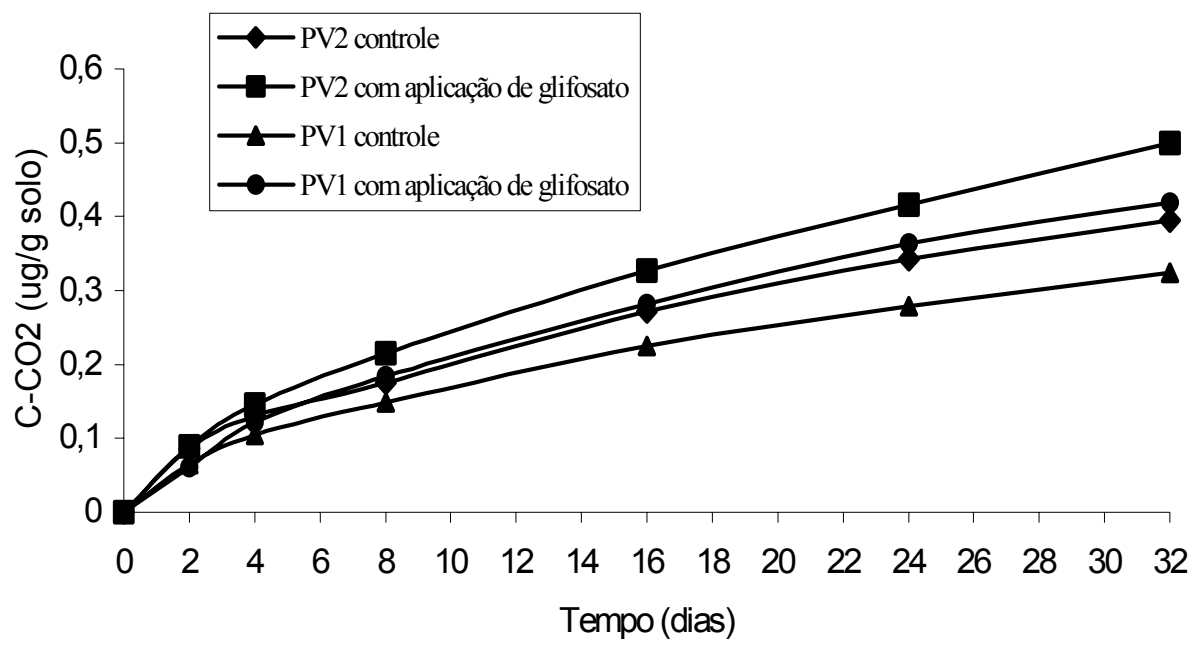

Figura 4 - Evolução de $\mathrm{CO}_{2}$ de amostras dos solos PV1 e PV2, durante o período de incubação de 32 dias, a $25^{\circ} \mathrm{C}( \pm 2)$ no escuro.

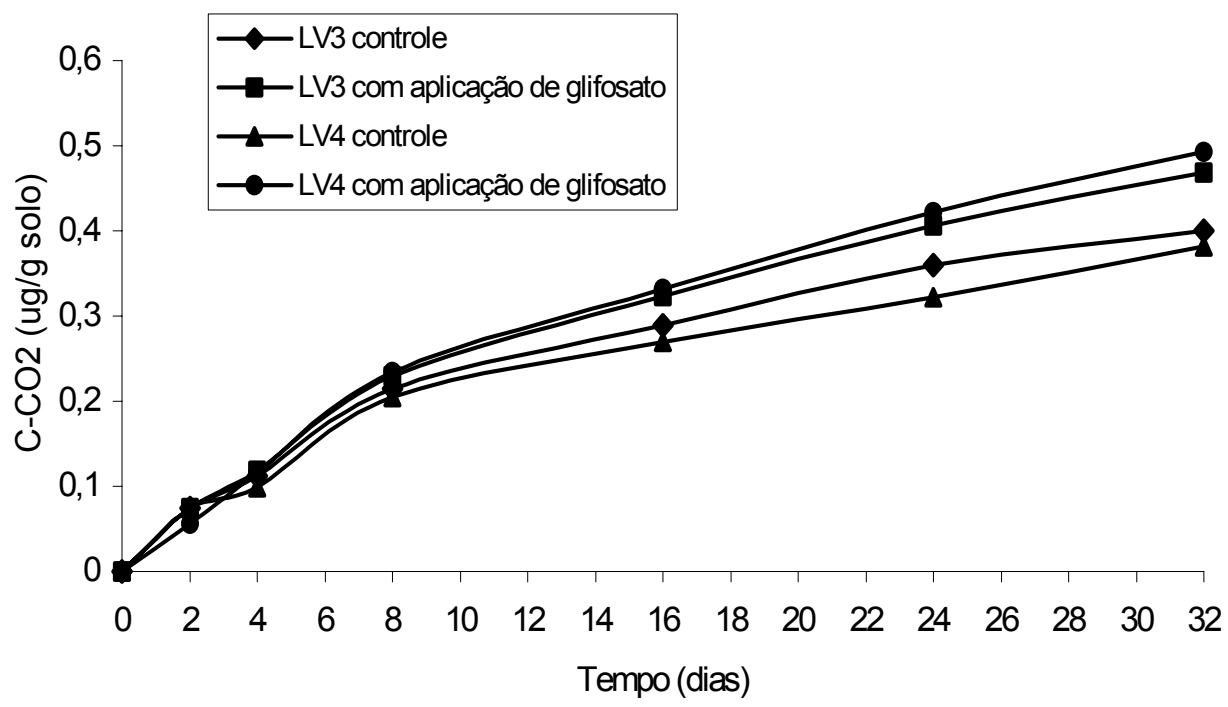

Figura 5 - Evolução de $\mathrm{CO}_{2}$ de amostras dos solos LV3 e LV4, durante o período de incubação de 32 dias, a $25^{\circ} \mathrm{C}( \pm 2)$ no escuro. 
Os resultados observados nas Figuras 4 e 5 mostram que em solos com histórico de aplicação de glifosato (PV 2 e LV 4) as quantidades de $\mathrm{CO}_{2}$ acumulado no período foi em torno de $10 \%$ a $15 \%$ superiores às observadas para os solos sem histórico de aplicação (PV 1 e LV 3). Os resultados ainda mostram que os solos que receberam aplicação do herbicida, na concentração inicial de 2,16 mg. $\mathrm{kg}^{-1}$, antes da incubação, apresentaram quantidades de $\mathrm{CO}_{2}$ desprendido em torno de $15 \%$ a $30 \%$ superiores, em relação aos solos controle, ao final do período de 32 dias. Na Tabela 3 são mostradas as quantidades de $\mathrm{CO}_{2}$ desprendido, devido a biodegradação do glifosato, sendo sua mineralização estimada em 0,10 mg/g, para os solos PV1 e PV2, e de 0,06 e $0,11 \mu \mathrm{g} / \mathrm{g}$, para os solos LV3 e LV4, respectivamente.

Estes resultados estão de acordo com os encontrados por Robertson \& Alexander (1994), que observaram que o glifosato foi rapidamente e extensivamente mineralizado após mais de uma aplicação. Os autores ainda observaram que $50 \%$ do herbicida aplicado foi mineralizado em 10 dias e que $60 \%$ do composto foi convertido para dióxido de carbono após uma segunda aplicação.

A semelhança no formato das curvas de evolução do $\mathrm{CO}_{2}$, encontrada nos solos avaliados, mostram que o glifosato não é diretamente utilizado como fonte de energia para a população microbiana. As amostras de solos avaliadas possuem quantidades semelhantes de matéria orgânica, que provavelmente foram utilizadas pelos microrganismos como fonte de energia. Segundo Sprankle et al. (1975a) o modelo de degradação do glifosato pelos microrganismos do solo sugere um processo de co-metabolismo. Esse mesmo processo é citado por outros autores que constataram que o glifosato não era completamente utilizado como fonte de energia para os microrganismos (Torstensson \& Aamisepp, 1977; Torstensson et al., 1989; Robertson \& Alexander, 1994; Forlani et al., 1999). 
Tabela 3. Quantidade de $\mathrm{CO}_{2}\left(\mu \mathrm{g} \cdot \mathrm{g}^{-1}\right.$ solo) desprendida pelos microrganismos devido a biodegradação do glifosato. Média de três repetições.

\begin{tabular}{ccccccc}
\hline Solos & \multicolumn{7}{c}{ Tempo } \\
\cline { 2 - 7 } & 02 dias & 04 dias & 08 dias & 16 dias & 24 dias & 32 dias \\
\hline PV1 & 0,001 & 0,018 & 0,035 & 0,056 & 0,085 & 0,10 \\
PV2 & 0,003 & 0,015 & 0,039 & 0,055 & 0,074 & 0,10 \\
LV3 & 0,001 & 0,006 & 0,015 & 0,034 & 0,046 & 0,06 \\
LV4 & 0,000 & 0,017 & 0,030 & 0,062 & 0,10 & 0,11 \\
\hline
\end{tabular}

\subsection{Atividade microbiana do solo}

Os resultados encontrados para a atividade microbiana dos solos utilizados no experimento de degradação, avaliados pela técnica da hidrólise de diacetato de fluoresceína (FDA), estão mostrados na Tabela 4. A técnica da hidrólise de FDA tem a vantagem de ser simples, rápida e sensível, e pode ser utilizadas para estudos comparativos de atividade microbiana em ambientes naturais (Schnürer \& Rosswall, 1982).

Comparando os resultados das amostras avaliadas, no início e final do período de incubação, observa-se que a atividade microbiana aumentou significativamente, para todos os solos avaliados, com a incubação em condições controladas de umidade e temperatura. Observou-se também que nas amostras de solos em que foi aplicado glifosato, antes do período de incubação, a atividade microbiana apresentou resultados superiores significativos em relação às amostras controles. Isto sugere que o glifosato é utilizado pelos microrganismos do solo para seu crescimento.

Observa-se também que os solos com histórico de aplicação do glifosato (PV 2 e LV 4) apresentaram atividade microbiana maior se comparados com os solos sem histórico de aplicação (PV 1 e LV 3), no início e 
no final do período de incubação. Estes resultados evidenciam que os solos com histórico de aplicação possuem uma microbiota mais ativa devido sucessivas aplicações do glifosato, além de proporcionar uma maior adaptação dos microrganismos à presença do produto. Os solos LV4 e PV2 apresentaram valores de 78,05 e 55,66 $\mu \mathrm{g} \mathrm{FDA} / \mathrm{g}$ de solo, com aplicação de glifosato aos 32 dias, respectivamente. Estes resultados foram superiores estatisticamente aos encontrados para os seus controles, que apresentaram valores de 72,45 e 49,39 $\mu \mathrm{g} \mathrm{FDA/g}$ de solo, respectivamente.

As diferentes taxas de degradação do glifosato está relacionada com a atividade microbiana apresentada pelo solo avaliado. Heinonen-Tanski (1989) sugere que solos com alta atividade microbiana favorecem a rápida degradação e o oposto ocorre em solos com baixa atividade, onde o glifosato pode permanecer intacto por mais tempo.

A atividade microbiana é um importante fator que influencia o comportamento do herbicida no ambiente. Segundo Haney et al. (2000) a aplicação de glifosato estimula rapidamente a atividade dos microrganismos do solo. Os autores ainda sugerem que o glifosato incrementa a atividade microbiana, através da mineralização do carbono e nitrogênio.

Os resultados de atividade microbiana, avaliada pela evolução do $\mathrm{CO}_{2}$ (Figuras 3 e 4), podem ser correlacionado com a atividade microbiana, medida pela hidrólise de FDA, apresentadas pelos solos avaliados. Observa-se que os solos que apresentaram atividades microbianas maiores, também mostraram uma maior quantidade de $\mathrm{CO}_{2}$ desprendido durante o período de incubação. Schnürer \& Rosswall (1982) detalharam que correlação acima de 90\% foi encontrada entre a hidrólise de FDA e a respiração microbiana e que as diferenças entre as camadas de solos pode ser reflexo do conteúdo da matéria orgânica presente. 
Tabela 4. Atividade microbiana de amostras de solo PV1, PV2, LV3 e LV4, no início e no final do período de incubação de 32 dias, a $25^{\circ} \mathrm{C}( \pm 2)$ no escuro. Média de cinco repetições.

\begin{tabular}{|c|c|c|c|}
\hline \multirow[t]{3}{*}{ Solos } & \multirow{3}{*}{$\begin{array}{c}\text { FDA ( } \mu \mathrm{g} \text { FDA/g solo) } \\
0 \text { dias }\end{array}$} & \multirow{2}{*}{\multicolumn{2}{|c|}{$\begin{array}{c}\text { FDA ( } \mu \mathrm{g} \text { FDA/g solo) } \\
32 \text { dias }\end{array}$}} \\
\hline & & & \\
\hline & & Controle & Glifosato \\
\hline PV 1 & $29,06 \mathrm{c}$ & $33,99 \mathrm{~b}$ & $41,56 a$ \\
\hline PV 2 & $48,26 \mathrm{c}$ & $49,39 \mathrm{~b}$ & 55,66 a \\
\hline LV 3 & $27,25 \mathrm{c}$ & $37,49 \mathrm{~b}$ & $46,61 \mathrm{a}$ \\
\hline LV 4 & $50,26 \mathrm{c}$ & $72,45 \mathrm{~b}$ & $78,05 a$ \\
\hline
\end{tabular}

${ }^{*}$ Médias, seguidas letras distintas na linha, diferem entre si pelo teste de Tukey em $5 \%$.

$\mathrm{Na}$ Figura 6 observa-se que as amostras de solo LV3 e LV4, provenientes do IAPAR, apresentaram atividades microbianas, aos 32 dias de incubação, entre $40 \%$ e $45 \%$ superiores em relação às atividades antes da incubação. Provavelmente estes solos exibam uma resposta positiva a incubação favorecendo um aumentos significativo de sua atividade microbiana. Já nas amostras de solo PV1 e PV2, provenientes da ESALQ, as maiores diferenças foram em relação às atividades microbianas entre os tratamentos com aplicação de glifosato e os controles, após o período de 32 dias de incubação, onde a aplicação do herbicida proporcionou um aumento de $15 \%$ a $25 \%$ na atividade para estes solos. Estes resultados sugerem que estes solos possuam uma microbiota mais sensível a aplicação do produto, que pode favorecer fontes adicionais de nutrientes. 


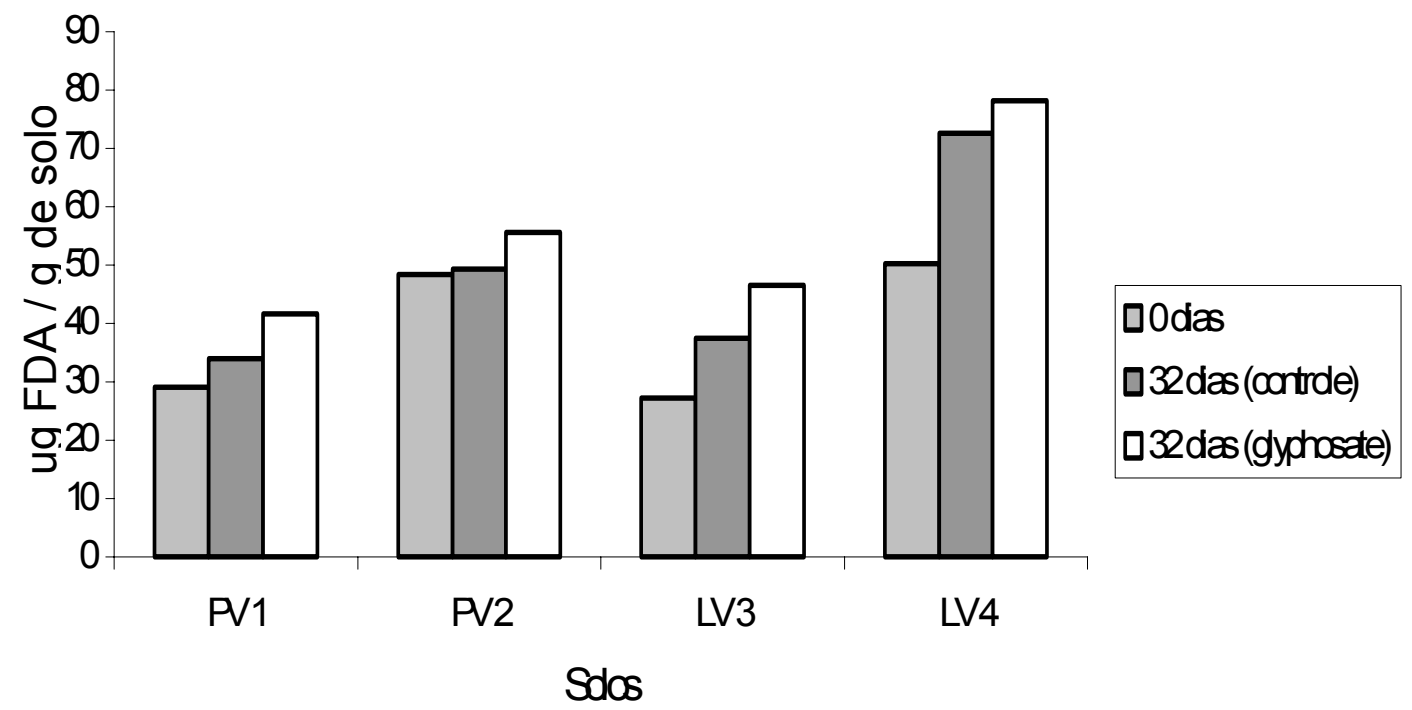

Figura 6 - Atividade microbiana das amostras de solo PV1, PV2, LV3 e LV4, no início e no final do período de incubação de 32 dias, a $25^{\circ} \mathrm{C}( \pm 2)$ no escuro.

\subsection{Quantificação de microrganismos do solo}

As contagens de microrganismos, nas amostras de solo analisadas, realizadas no início e no final do experimento de degradação, estão mostrados nas Tabelas 5, 6 e 7.

Observa-se, de uma maneira geral que o número de bactérias sofreu um pequeno decréscimo com a aplicação de glifosato ao solo, enquanto que no número de fungos e actinomicetos houve um aumento significativo após o período de 32 dias.

A Tabela 5 mostra os resultados das amostras de solo PV e LV ,em relação ao número de bactérias, no início e final do período de incubação. Observa-se que nos solos PV 1 e LV 3 ( sem histórico de aplicação), o número de bactérias encontradas foram de $5 \times 10^{5}$ e $9,1 \times 10^{5} \mathrm{UFC} / \mathrm{g}$ solo, no início, e 
de $1,8 \times 10^{5}$ e $6,3 \times 10^{5} \mathrm{UFC} / \mathrm{g}$ de solo, no final, respectivamente. Apresentando, portanto, pequena diminuição do número de bactérias após o período de 32 dias com aplicação do glifosato.

Os solos PV 2 e LV 4 (com histórico de aplicação) apresentaram número de bactérias de $5 \times 10^{5}$ e $8,5 \times 10^{5} \mathrm{UFC} / \mathrm{g}$ solo, no início, e de $7 \times 10^{5} \mathrm{e}$ $7,8 \times 10^{5} \mathrm{UFC} / \mathrm{g}$ de solo, no final, respectivamente. Mostrando que não houve diminuição no número de bactérias após o período de incubação. Provavelmente estes solos provenientes de áreas com histórico de aplicação possua uma comunidade bacteriana adaptada, onde o glifosato não apresentaria efeitos adversos sobre este grupo de microrganismo.

Estes resultados, entretanto, mostram que o glifosato pode apresentar pequenos efeitos negativos ou positivos às bactérias do solo. Anderson (1978) reportou que os herbicidas, utilizados normalmente nas doses recomendadas, não têm efeitos adversos sobre as bactérias. Wardle \& Parkinson (1990b) estudaram a influência do glifosato sobre a comunidade microbiana do solo e observaram que houve um crescimento temporário no número de bactérias.

Em relação aos fungos, os resultados observados na Tabela 6 mostram que houveram aumentos significativos no número de fungos para todos os solos avaliados, no final do período de incubação, se comparados com os resultados obtidos no início da incubação. Além disso, as amostras de solo que receberam aplicação de glifosato mostraram número de fungos estatisticamente superiores, se comparados com as amostras controle, aos 32 dias de incubação. 
Tabela 5. Número de bactérias nas amostras de solos PV1, PV2, LV3 e LV4, no início e no final do período de incubação de 32 dias. Média de três repetições.

\begin{tabular}{crrr}
\hline Solos & (U.F.C./g solo) & \multicolumn{2}{c}{ (U.F.C./g solo) } \\
& 0 dias & \multicolumn{2}{c}{32 dias } \\
\cline { 3 - 4 } & & Controle & Glifosato \\
\hline PV 1 & $5 \times 10^{5} \mathrm{a}$ & $2,2 \times 10^{5} \mathrm{a}$ & $1,8 \times 10^{5} \mathrm{a}$ \\
PV 2 & $5 \times 10^{5} \mathrm{a}$ & $4 \times 10^{5} \mathrm{a}$ & $7 \times 10^{5} \mathrm{~b}$ \\
LV 3 & $9,1 \times 10^{5} \mathrm{a}$ & $4,9 \times 10^{5} \mathrm{a}$ & $6,3 \times 10^{5} \mathrm{a}$ \\
LV 4 & $8,5 \times 10^{5} \mathrm{a}$ & $10,5 \times 10^{5} \mathrm{a}$ & $7,8 \times 10^{5} \mathrm{a}$ \\
\hline
\end{tabular}

*Médias, seguidas pela mesma letra na linha, não diferem entre si pelo teste de Tukey em $5 \%$.

Os resultados ainda mostram que o solo LV4, com valor 5,3 $\times 10^{4}$ UFC/g de solo, apresentou número de fungos, após o período de 32 dias, com aplicação do glifosato, superior aos outros tratamentos na mesma condição e

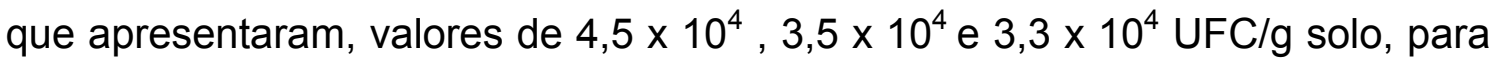
os solos PV1, PV2 e LV3, respectivamente. Provavelmente a cobertura vegetal permanentemente presente neste solo, além de um histórico de aplicação mais longo, tenha proporcionado uma comunidade fúngica mais numerosa.

Segundo Wardle \& Parkinson (1990b) o glifosato pode influenciar diretamente a população fúngica ou também ter efeitos indiretos, por influencia de outros microrganismos que interagem com os fungos. Estes resultados sugerem que os fungos possuem uma capacidade de assimilação e degradação de herbicidas utilizando como fonte de nutrientes para o seu metabolismo. No caso do glifosato, os fungos utilizam o herbicida, provavelmente como fonte de carbono e fósforo. Bujacz et al. (1995) citaram que os fungos possuem um enorme potencial de degradação de compostos organofosforados, tais como o glifosato, devido ao seu mecanismo de clivagem da ligação C-P da molécula. 
Tabela 6. Número de fungos nas amostras de solos PV1, PV2, LV3 e LV4, no início e no final do período de incubação de 32 dias. Média de três repetições.

\begin{tabular}{|c|c|c|c|}
\hline \multirow[t]{3}{*}{ Solos } & \multirow{3}{*}{$\begin{array}{c}\text { (U.F.C./g solo) } \\
0 \text { dias }\end{array}$} & \multicolumn{2}{|c|}{ (U.F.C./g solo) } \\
\hline & & \multicolumn{2}{|c|}{32 dias } \\
\hline & & Controle & Glifosato \\
\hline PV1 & $1 \times 10^{3} \mathrm{c}$ & $1,6 \times 10^{4} b$ & $4,5 \times 10^{4} a$ \\
\hline PV2 & $5 \times 10^{4} \mathrm{c}$ & $1,7 \times 10^{4} b$ & $3,5 \times 10^{4} a$ \\
\hline LV3 & $6,2 \times 10^{3} \mathrm{c}$ & $9,2 \times 10^{3} \mathrm{~b}$ & $3,3 \times 10^{4} a$ \\
\hline LV4 & $8,7 \times 10^{3} \mathrm{c}$ & $8 \times 10^{3} \mathrm{~b}$ & $5,3 \times 10^{4} a$ \\
\hline
\end{tabular}

*Médias, seguidas pela mesma letra na linha, não diferem entre si pelo teste de Tukey em $5 \%$.

$\mathrm{Na}$ Tabela 7 são mostrados os resultados relativos ao número de actinomicetos das amostras dos solos avaliadas no início e no final do período de incubação. De acordo com esses resultados, observa-se que o número de actinomicetos aumentou significativamente após o período de 32 dias de incubação, se comparado com os resultados obtidos antes da incubação. As amostras de solo que receberam aplicação de glifosato mostram número de actinomicetos estatisticamente superiores, se comparados com as amostras controle, aos 32 dias de incubação.

Obojska et al. (1999) estudando a degradação de organofosforados, dentre eles o glifosato, por isolados de Streptomycetes observaram que estes microrganismos são capazes de utilizar compostos contendo ligação C-P como fonte de fósforo. 
Tabela 7. Número de actinomicetos nas amostras de solos PV1, PV2, LV3 e LV4, no início e no final do período de incubação de 32 dias. Média de três repetições.

\begin{tabular}{crrr}
\hline Solos & (U.F.C./g solo) & \multicolumn{2}{c}{ (U.F.C./g solo) } \\
& 0 dias & \multicolumn{2}{c}{32 dias } \\
\cline { 3 - 4 } & & Controle & Glifosato \\
\hline PV 1 & $2,4 \times 10^{5} \mathrm{c}$ & $6,4 \times 10^{5} \mathrm{~b}$ & $5,4 \times 10^{6} \mathrm{a}$ \\
PV 2 & $4 \times 10^{5} \mathrm{~b}$ & $1,5 \times 10^{6} \mathrm{a}$ & $2,4 \times 10^{6} \mathrm{a}$ \\
LV 3 & $1,2 \times 10^{5} \mathrm{c}$ & $6,7 \times 10^{4} \mathrm{~b}$ & $5,5 \times 10^{5} \mathrm{a}$ \\
LV 4 & $8 \times 10^{5} \mathrm{~b}$ & $3,4 \times 10^{5} \mathrm{~b}$ & $2,5 \times 10^{6} \mathrm{a}$ \\
\hline
\end{tabular}

*Médias, seguidas pela mesma letra na linha, não diferem entre si pelo teste de Tukey em $5 \%$.

\subsection{Extração e análise de glifosato do solo}

Os resultados obtidos na recuperação de glifosato variaram entre os tipos de amostras de solo. A porcentagem de recuperação encontrada para a amostra de solo PV 1 foi de $110 \%$ e para a amostra de solo PV 2 foi de $98 \%$; já a porcentagem de recuperação de glifosato na amostra de solo LV 3 foi de $72 \%$ e para amostra de solo LV 4 foi de $71 \%$, com uma dose de aplicação inicial de 2,16 mg. $\mathrm{kg}^{-1}$ de glifosato para todas as amostras (Tabela 8). Os resultados mostram a dificuldade de extração de glifosato em solos com alto conteúdo de argila, apresentados pelas amostras de solo LV3 e LV4, que possuem $86 \%$ e $91 \%$ de argila, respectivamente. A composição física e química do solo tem forte influência na adsorção do herbicida, principalmente o conteúdo de argila, ferro e alumínio. Spann \& Hargreaves (1994) analisaram solos com moderado a alto conteúdo de argila, através de extração alcalina com 0,1 M de hidróxido de potássio e uma etapa de limpeza do extrato utilizando coluna de troca catiônica, e encontraram recuperações que variaram entre $80 \%$ a $90 \%$ de glifosato 
aplicado. Outros autores encontraram resultados entre $45 \%$ a $92 \%$ de recuperação de glifosato em solos com conteúdo de argila em torno de $40 \%$ a 87\% (Roy \& Konar, 1989; Aubin \& Smith, 1992; Alferness \& Iwata, 1994; Souza et al., 1999a).

Tabela 8. Recuperação de glifosato dos solos PV1, PV2, LV3 e LV4. Média de três repetições ( \pm desvio padrão).

\begin{tabular}{ccc}
\hline Solos & $\begin{array}{c}\text { Glifosato } \\
\left(\mathrm{mg}^{\mathrm{kg}}{ }^{-1}\right)\end{array}$ & $\begin{array}{c}\text { Glifosato } \\
(\%)\end{array}$ \\
\hline PV 1 & $2,116( \pm 0,03)$ & $98( \pm 1,64)$ \\
PV 2 & $2,370( \pm 0,03)$ & $110( \pm 0,47)$ \\
LV 3 & $1,535( \pm 0,01)$ & $72( \pm 0,60)$ \\
LV 4 & $1,530( \pm 0,01)$ & $71 \pm \pm 0,53)$ \\
\hline
\end{tabular}

Os métodos de extração que usam soluções alcalinas são mais eficientes, pois possibilitam uma melhor recuperação do herbicida aplicado no solo. O uso de hidróxido de amônia como solução extratora possibilitou um aumento do $\mathrm{pH}$ do extrato, até valores superiores a $\mathrm{pH} 9,0$, tornando possível uma recuperação eficiente, devido à mudanças das cargas eletrostáticas do glifosato, e favorecendo sua dessorção das partículas do solo. De acordo com Sprankle et al. (1975), o glifosato apresenta as seguintes constantes de dissociação: 2,0, 2,6, 5,6 e 10,6 (Figura 7). A pH abaixo de 2,0, o glifosato apresenta carga líquida positiva, o que contribui para a sua adsorção à argila e matéria orgânica do solo que têm cargas negativas. A pH 2,6, o glifosato tem carga zero e acima deste valor, sua carga negativa aumenta com aumento do $\mathrm{pH}$. A pH 12, praticamente todo o glifosato está em sua forma trianionica, sem nenhuma carga positiva (Grossbard \& Atkinson, 1985). Por conseguinte, 
condições alcalinas contribuem para aumentar a eficiência da extração de glifosato do solo que também tem carga negativa nestas condições (Spann \& Hargreaves, 1994). A adição de fosfato pode aumentar a recuperação de glifosato, devido a competição do fosfato com o glifosato por sítios de adsorção no solo. Alferness \& Iwata (1994) relataram que a adição de fosfato possibilita um incremento na recuperação do glifosato do solo.

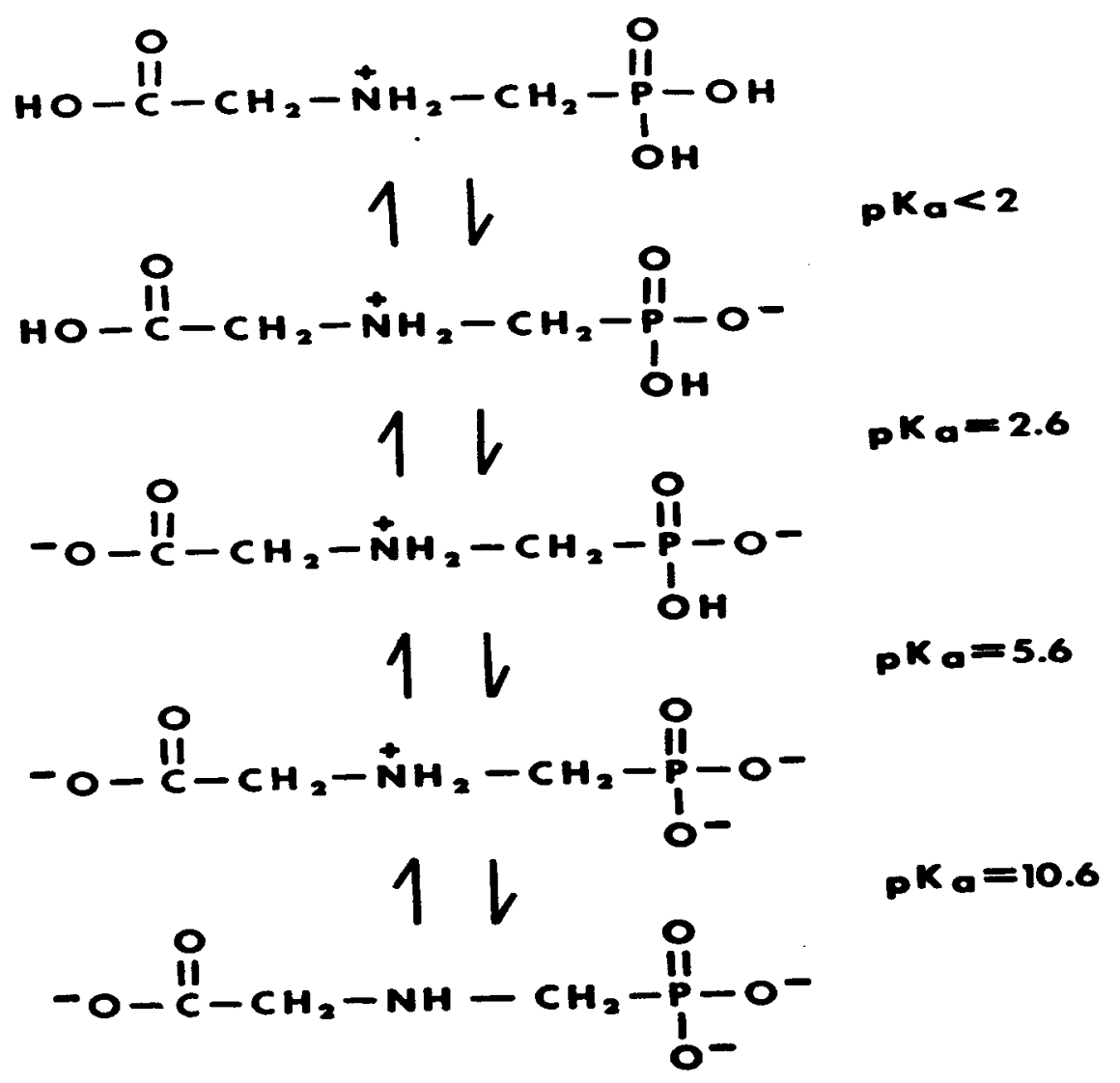

Figura 7 - Constantes de dissociação e ionização para glifosato (Sprankle et al., 1975). 
Os resultados encontrados após o período de incubação (32 dias) mostram que a quantidade de glifosato apresentou diminuição no solo, com valores de $0,148 \mathrm{mg} \cdot \mathrm{kg}^{-1} ; 0,139 \mathrm{mg} \cdot \mathrm{kg}^{-1} ; 0,202 \mathrm{mg} \cdot \mathrm{kg}^{-1}$ e $0,461 \mathrm{mg} \cdot \mathrm{kg}^{-1}$ para as amostras de solo PV1, PV2, LV3 e LV4, respectivamente. O metabólito AMPA foi encontrado nessas amostras de solo após o período de incubação, mostrando ser o principal produto da degradação de glifosato. A quantidade de AMPA encontrada nas amostras de solo PV1, PV2, LV3 e LV4 foi de 0,504 $\mathrm{mg} \cdot \mathrm{kg}^{-1} ; 0,788 \mathrm{mg} \cdot \mathrm{kg}^{-1} ; 0,446 \mathrm{mg} \cdot \mathrm{kg}^{-1}$ e $0,677 \mathrm{mg} \cdot \mathrm{kg}^{-1}$, respectivamente (Tabela 9). Nas amostras testemunhas não foram detectadas a presença de glifosato e AMPA, exceto nas amostras de solo PV2 e LV4, que apresentaram concentrações de $0,18 \mathrm{mg} \cdot \mathrm{kg}^{-1}$ e $0,043 \mathrm{mg} \cdot \mathrm{kg}^{-1}$ de AMPA. Provavelmente, o aparecimento dessas pequenas concentrações de AMPA nessas amostras seja devido às constantes aplicações de glifosato nestes solos. De acordo com os resultados encontrados após o período de incubação de 32 dias, o glifosato foi degradado para o seu principal metabólito AMPA, e o método de extração e análise utilizados tornou possível a sua detecção no extrato.

O uso de agitador horizontal possibilitou uma melhor recuperação do glifosato e AMPA nas amostras de solo. Os agitadores horizontais são mais eficientes na desagregação do solo, contribuindo na recuperação do produto. Resultados semelhantes foram observados por Spann \& Hargreaves (1994), que obtiveram aumento de recuperação de glifosato utilizando agitadores horizontais para desagregar o solo. O tempo de agitação dos tubos foi outro fator importante observado para uma extração mais eficiente, pois tempos maiores de exposição do solo com os extratores provêem uma recuperação mais eficiente. Aubin \& Smith (1992) usando vários extratores para recuperação do glifosato do solo, observaram que a exposição do produto a grandes períodos de agitação aumentou a sua recuperação. 
Tabela 9. Quantidade de glifosato e AMPA das amostras de solos PV1, PV2, LV3 e LV4. Antes e após período de incubação de 32 dias, no escuro. Média de três repetições ( \pm desvio padrão).

\begin{tabular}{|c|c|c|c|c|}
\hline \multirow[t]{2}{*}{ Solos } & \multicolumn{2}{|c|}{0 dias } & \multicolumn{2}{|c|}{32 dias } \\
\hline & $\begin{array}{l}\text { Glifosato } \\
\left(\mathrm{mg} \cdot \mathrm{kg}^{-1}\right)\end{array}$ & $\begin{array}{c}\text { AMPA } \\
\left(\mathrm{mg} \cdot \mathrm{kg}^{-1}\right)\end{array}$ & $\begin{array}{l}\text { Glifosato } \\
\left(\mathrm{mg} \cdot \mathrm{kg}^{-1}\right)\end{array}$ & $\begin{array}{c}\text { AMPA } \\
\left(\mathrm{mg} \cdot \mathrm{kg}^{-1}\right)\end{array}$ \\
\hline PV1 & $2,116( \pm 0,03)$ & nd & $0,148( \pm 0,03)$ & $0,504( \pm 0,6)$ \\
\hline Cont. & nd & nd & - & - \\
\hline PV2 & $2,370( \pm 0,10)$ & $0,18( \pm 0,4)$ & $0,139( \pm 0,10)$ & $0,788( \pm 0,4)$ \\
\hline Cont. & nd & $0,18( \pm 0,4)$ & - & - \\
\hline LV3 & $1,535( \pm 0,01)$ & nd & $0,202( \pm 0,01)$ & $0,446( \pm 0,6)$ \\
\hline Cont. & nd & nd & - & - \\
\hline LV4 & $1,530( \pm 0,01)$ & nd & $0,461 \quad( \pm 0,01)$ & $0,677( \pm 0,5)$ \\
\hline Cont. & nd & nd & - & - \\
\hline
\end{tabular}

O solo apresenta vários interferentes que podem prejudicar a análise do produto, devendo ser removidos através de um cleanup eficiente das amostras. De acordo com Milles \& Moye (1988) o sucesso da determinação de glifosato no solo, requer uma eficiente extração seguida por etapa de cleanup da amostra. A utilização de coluna de troca catiônica para a etapa de cleanup é um procedimento importante (Spann \& Hargreaves, 1994). Porém, é necessário ajustar o pH do extrato para 2,0, antes de passar pela coluna de troca catiônica, pois o glifosato a pH 2,0 apresenta carga positiva, possibilitando sua interação com os componentes da resina trocadora de cations.

O limite de detecção neste trabalho foi de $0,01 \mathrm{mg} \cdot \mathrm{kg}^{-1}$ para glifosato e AMPA. O limite de quantificação foi de $0,1 \mathrm{mg} \cdot \mathrm{kg}^{-1}$ para amostras de solo. As equações de regressão e coeficientes de correlação das curvas para padrões 
de glifosato e AMPA foram: glifosato: $Y=49173 X+742,59\left(r^{2}-0,99\right)$; AMPA: $y=75026 x\left(r^{2}-1\right)($ Tabela 10).

Tabela 10. Equações de calibração para determinações cromatográficas de glifosato e AMPA.

\begin{tabular}{lcc}
\hline Composto & Equação & $r^{2}$ \\
\hline Glifosato & $y=49173 x+742,59$ & 0,9999 \\
AMPA & $y=75026 x$ & 1 \\
\hline
\end{tabular}

O glifosato e o AMPA foram analisados por HPLC com reação derivatização pos-coluna, específico para aminas primárias. O glifosato é oxidado com hipoclorito de cálcio e o produto da reação (glicina) e AMPA são misturados com OPA na presença de mercaptoetanol dando fluoroforos (isoindols) que são quantificados por HPLC com detector de fluorescência. A detecção por fluorescência com OPA-ME exibe características de seletividade ligeiramente superiores (Schuster \& Gratzfeld-Husgen, 1992). Os resultados encontrados mostram que este equipamento apresenta grande detectabilidade, sensibilidade e eficiência, pois observa-se que o cromatogramas apresentam alta confiança na identificação e quantificação do glifosato. As equações de calibração apresentadas na Tabela 10, relacionadas com os cromatogramas da Figura 8, mostram que a deteç̧ão do glifosato permitiu um eficiente ajuste de regressão com alta qualidade. Os cromatogramas obtidos de glifosato e AMPA extraídos dos solo PV1 (Figura 9), PV2 (Figura 10), LV3 (Figura 11) e LV4 (Figura 12), mostram-se bastantes seletivos em relação aos compostos separados. Além disso, observa-se que os cromatogramas controle (testemunha) das amostras analisadas não detectaram nenhum pico de glifosato e AMPA nos extratos, exceto para o solo PV2, que apresentou uma 
pequena concentração de AMPA (Figuras 13 e 14). Glass (1983) demonstrou que método por HPLC é reproduzível e sensível para a determinação de glifosato em amostras ambientais.

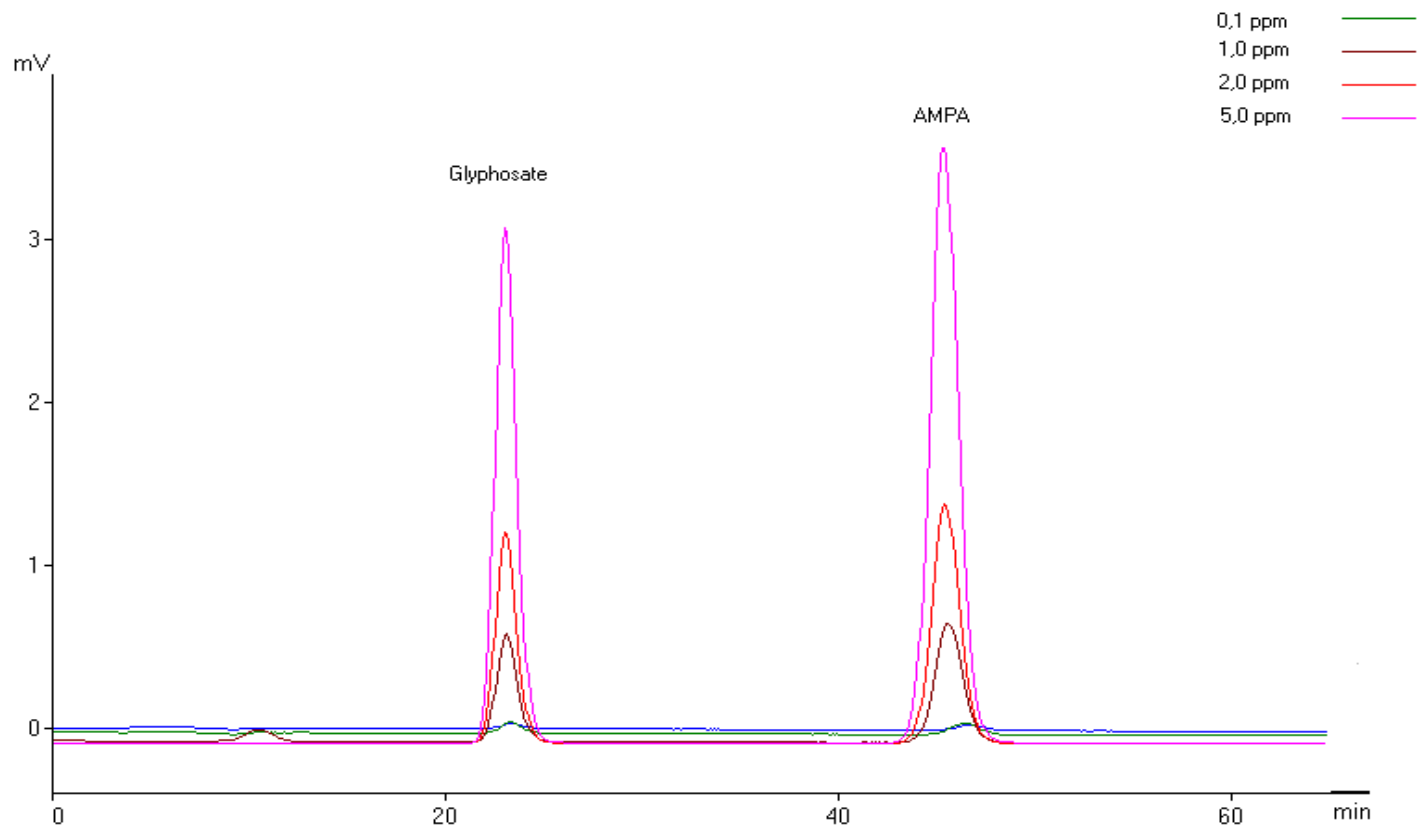

Figura 8 - Cromatogramas de concentrações padrão de glifosato e AMPA derivatizadas com OPA-ME. Condição: fase móvel é $0.08 \mathrm{M} \mathrm{K}_{2} \mathrm{PO}_{4}$ a $0.5 \mathrm{~mL} \cdot \mathrm{min}^{-1}$. Detector de fluorescência a $E_{x} 350 \mathrm{~nm}$ e $E_{m} 440 \mathrm{~nm}$. 


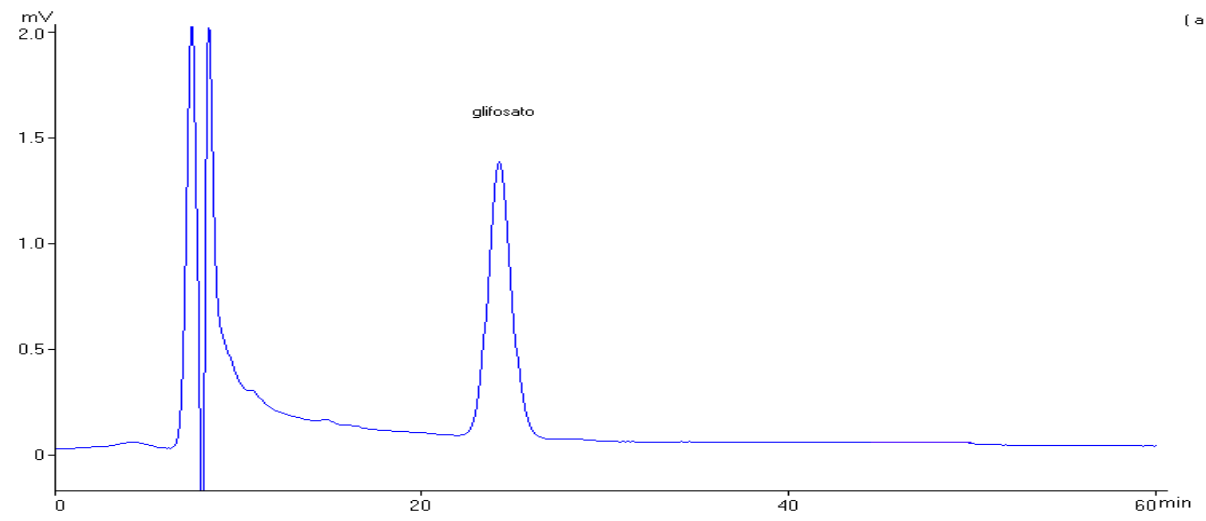

(a)
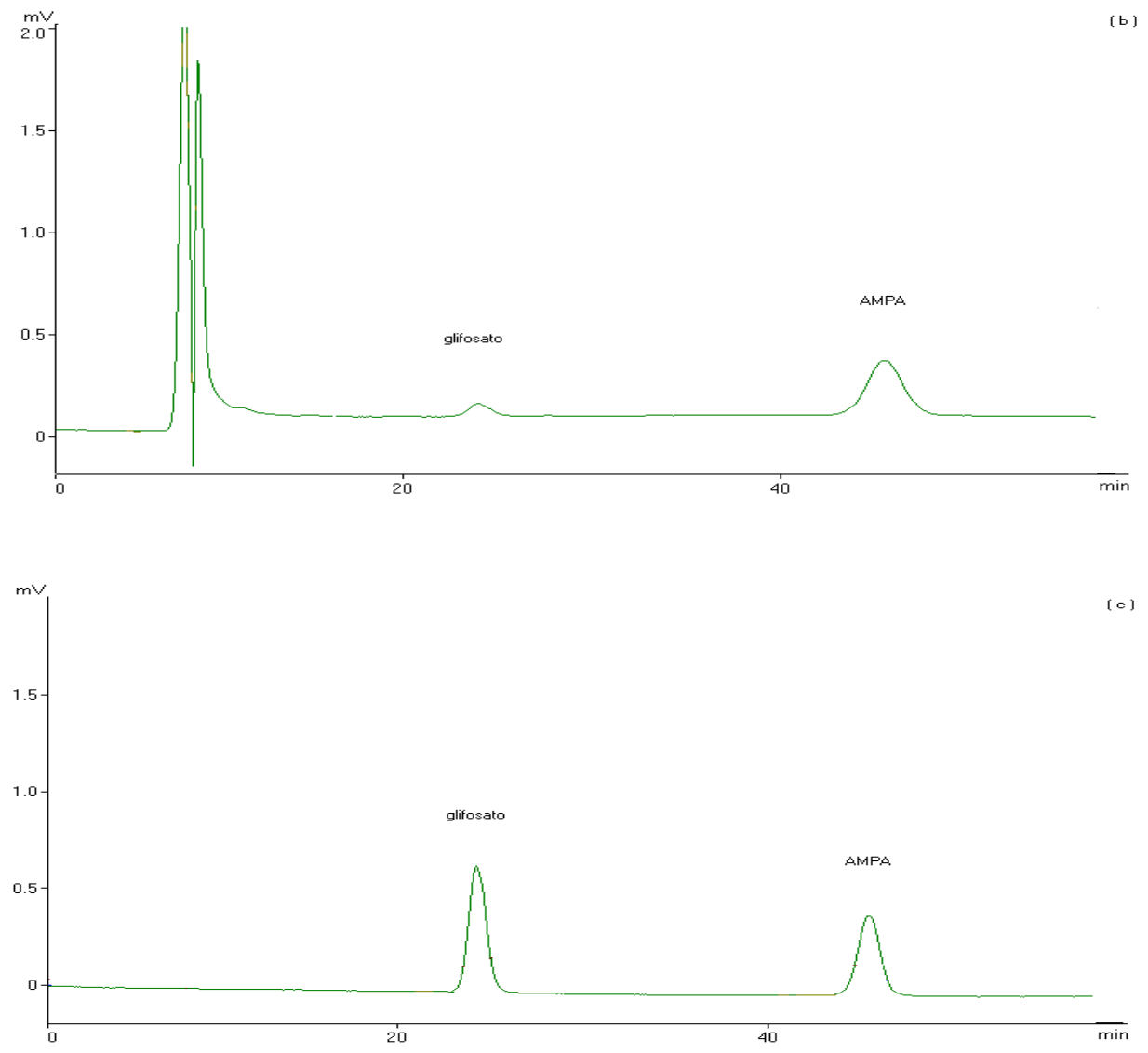

Figura 9 - Cromatogramas de glifosato e AMPA extraídos do solo PV1, aos 0 dias (a), e 32 dias (b) e padrão de 1 ppm (c), derivatizadas com OPAME. Condição: fase móvel é $0.08 \mathrm{M} \mathrm{K}_{2} \mathrm{PO}_{4}$ a $0.5 \mathrm{~mL} \cdot \mathrm{min}^{-1}$. Detector de fluorescência a $E_{x} 350 \mathrm{~nm}$ e $E_{m} 440 \mathrm{~nm}$. 


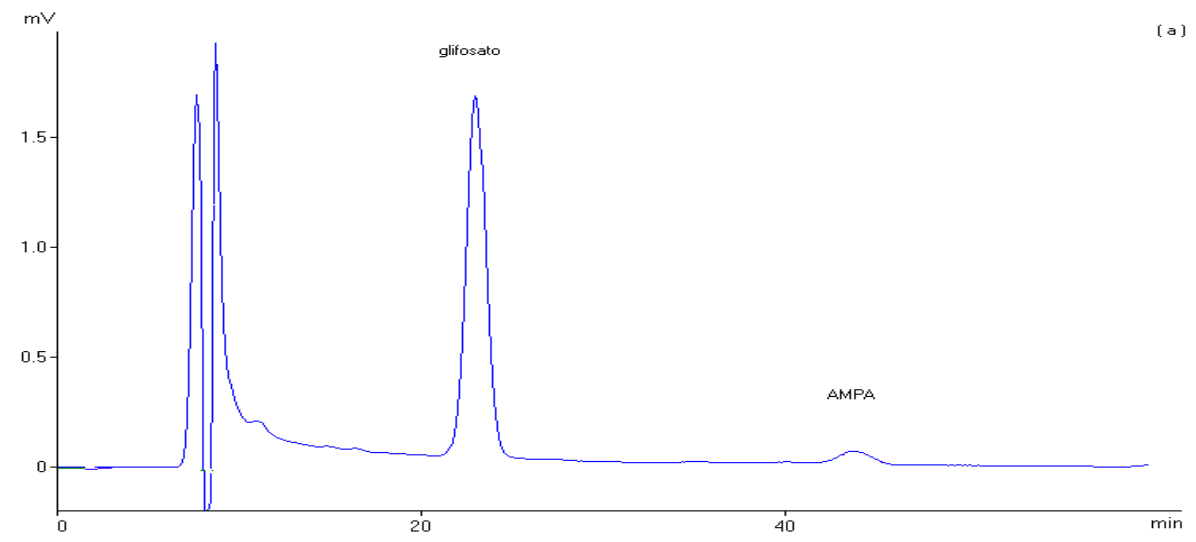

(2)
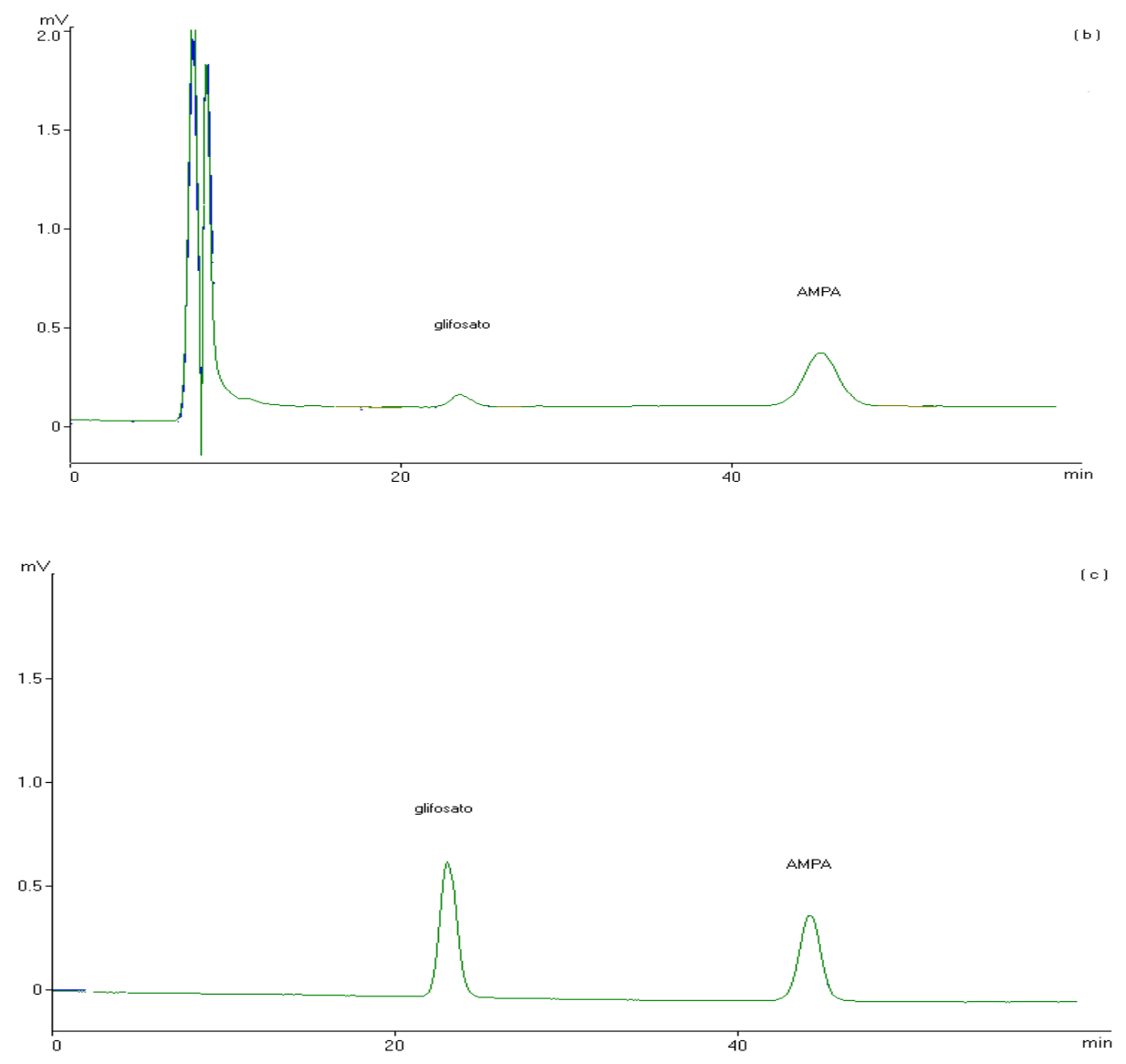

Figura 10 - Cromatogramas de glifosato e AMPA extraídos do solo PV2 aos 0 dias (a) e 32 dias (b) e padrão de 1 ppm (c), derivatizadas com OPA-ME. Condição: fase móvel é $0.08 \mathrm{M} \mathrm{K}_{2} \mathrm{PO}_{4}$ a $0.5 \mathrm{~mL} \cdot \mathrm{min}^{-1}$. Detector de fluorescência a $E_{x} 350 n m$ e $E_{m} 440 \mathrm{~nm}$. 


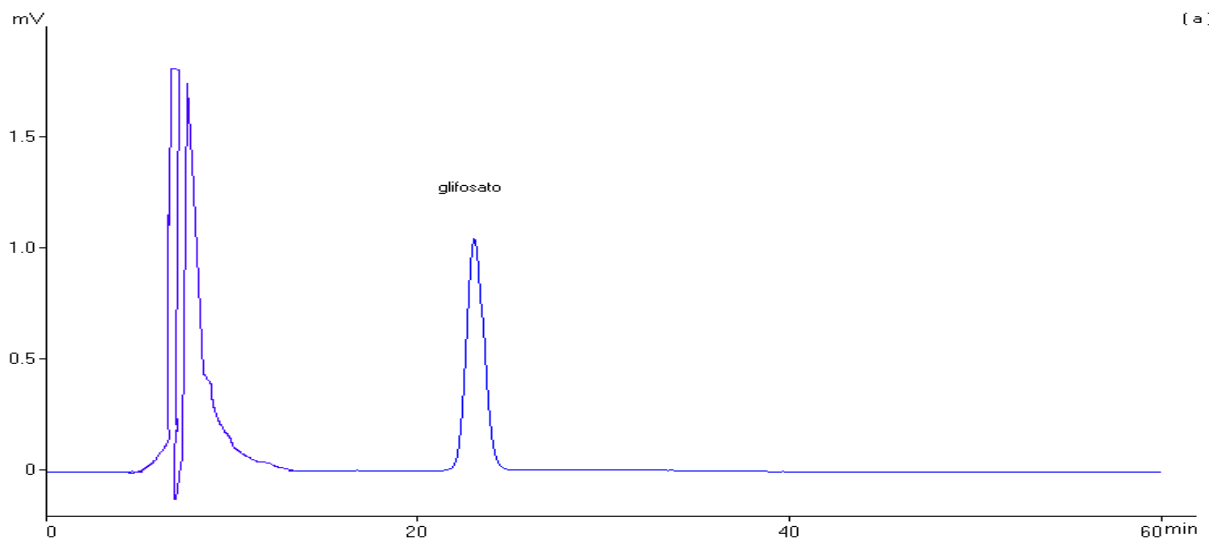

(a)

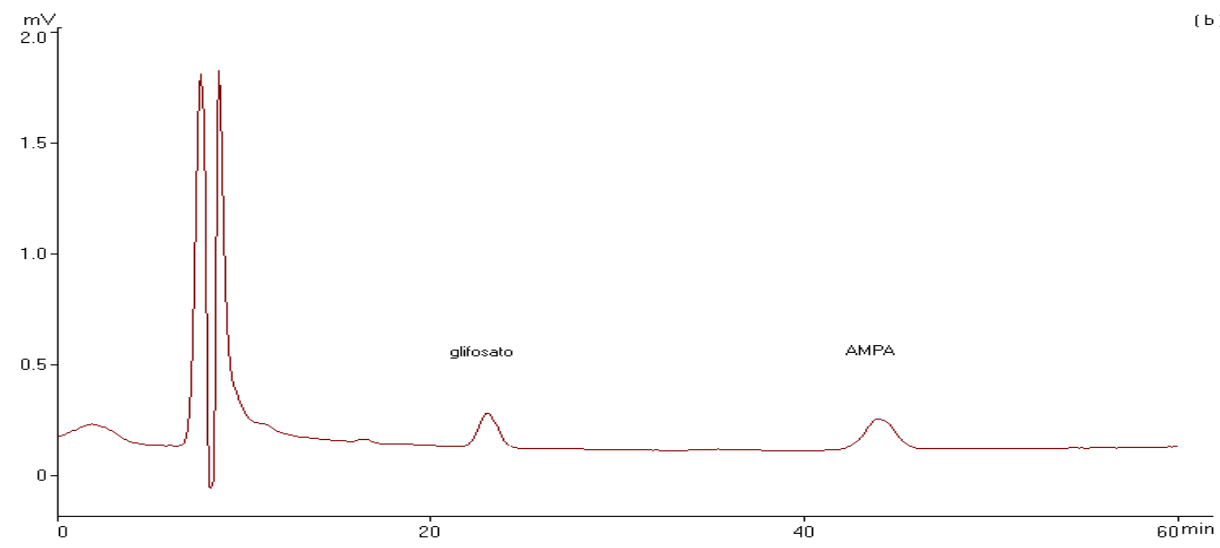

(b)

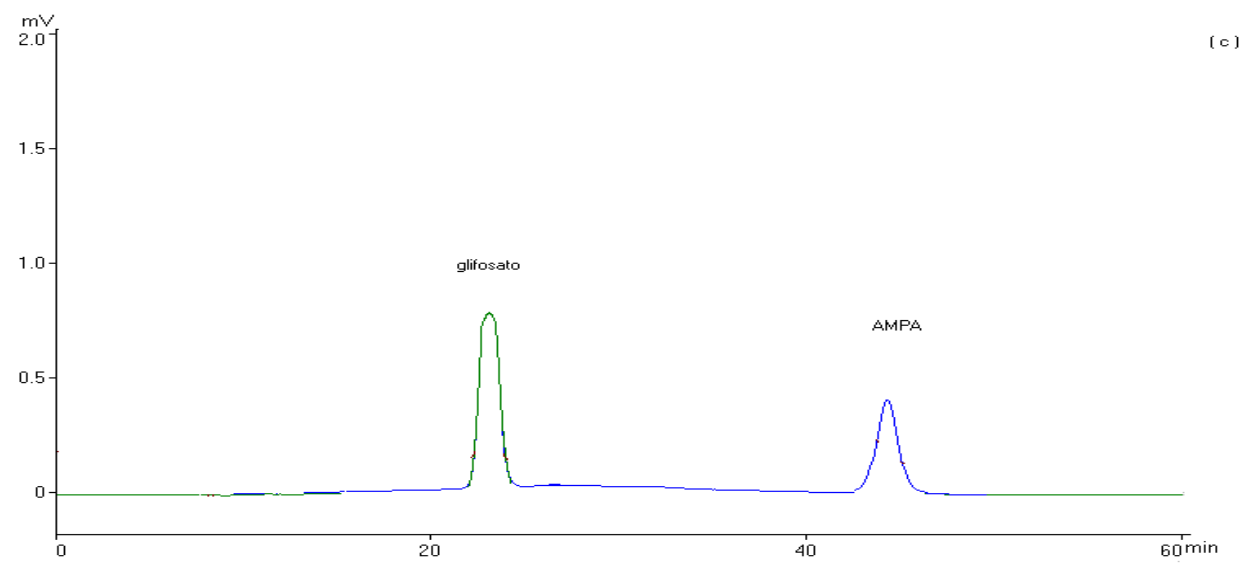

Figura 11 - Cromatogramas de glifosato e AMPA extraídos do solo LV3, aos 0 dias (a) e 32 dias (b) e padrão de 1 ppm (c), derivatizadas com OPA-ME. Condição: fase móvel é $0.08 \mathrm{M} \mathrm{K}_{2} \mathrm{PO}_{4}$ a $0.5 \mathrm{~mL} \cdot \mathrm{min}^{-1}$. Detector de fluorescência a $E_{x} 350 n m$ e $E_{m} 440 \mathrm{~nm}$. 

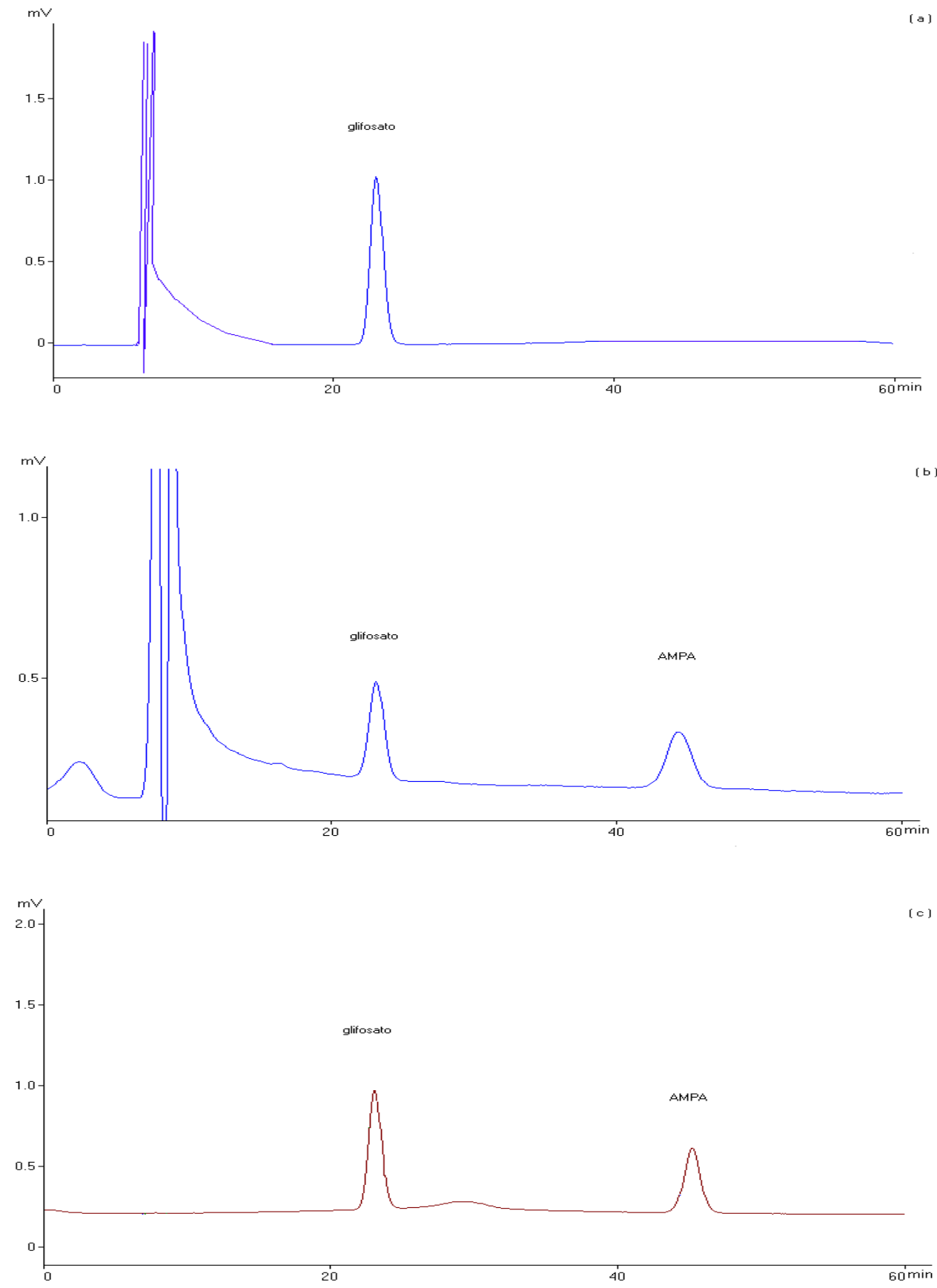

Figura 12 - Cromatogramas de glifosato e AMPA extraídos do solo LV4, aos 0 dias (a) e 32 dias (b), derivatizadas com OPA-ME. Condição: fase móvel é $0.08 \mathrm{M} \mathrm{K}_{2} \mathrm{PO}_{4}$ a $0.5 \mathrm{~mL} \cdot \mathrm{min}^{-1}$. Detector de fluorescência a $E_{x} 350 n m$ e $E_{m} 440 \mathrm{~nm}$. 

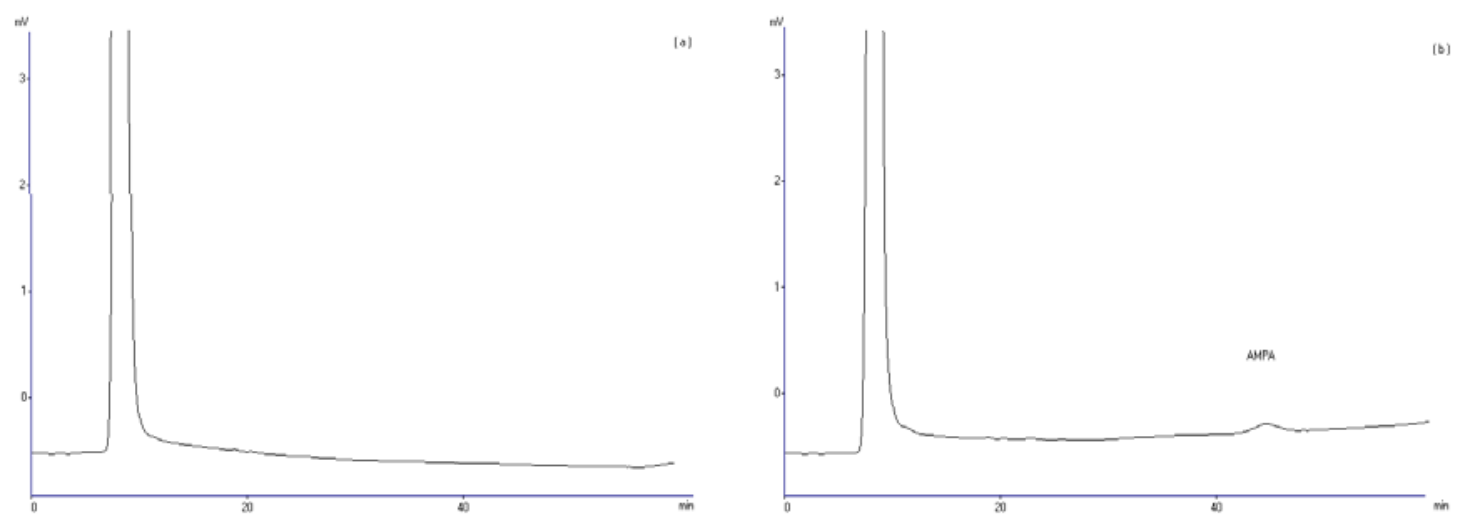

Figura 13 - Cromatogramas de glifosato e AMPA extraído das amostras dos solos PV1 (a) e PV2 (b) (controle), derivatizadas com OPA-ME. Condição: fase móvel é $0.08 \mathrm{M} \mathrm{K}_{2} \mathrm{PO}_{4}$ a $0.5 \mathrm{~mL} \cdot \mathrm{min}^{-1}$. Detector de fluorescência a $E_{x} 350 n m$ e $E_{m} 440 \mathrm{~nm}$.
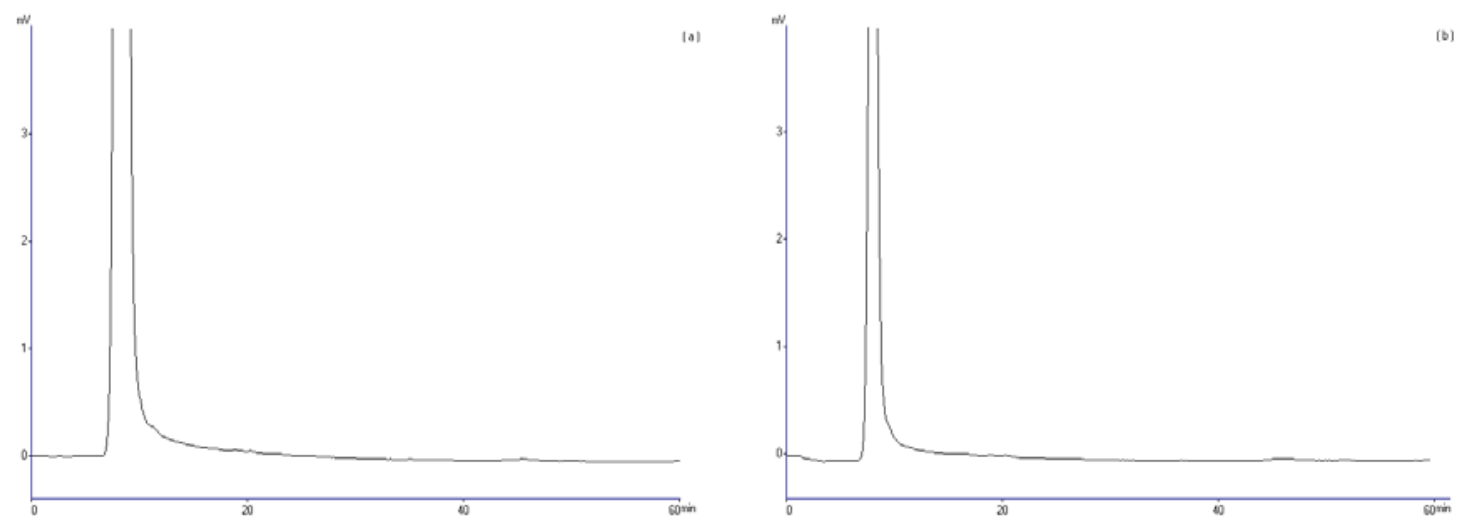

Figura 14 - Cromatogramas de glifosato e AMPA extraídos das amostras dos solos LV3 (a) e LV4 (b) (controle), derivatizadas com OPA-ME. Condição: fase móvel é $0.08 \mathrm{M} \mathrm{K}_{2} \mathrm{PO}_{4}$ a $0.5 \mathrm{~mL} \cdot \mathrm{min}^{-1}$. Detector de fluorescência a $E_{x} 350 n m$ e $E_{m} 440 \mathrm{~nm}$. 
Os resultados obtidos na quantificação de resíduos de glifosato e AMPA das amostras de solos analisadas aos 0, 8, 16 e 32 dias após aplicação do glifosato estão apresentados na Tabela 11. De acordo com os resultados observa-se uma diminuição da quantidade do glifosato, com conseqüente aparecimento do metabólito AMPA.

Observa-se que nas amostras de solo PV2 e LV4, com histórico de aplicação do herbicida, a quantidade de AMPA encontrada no final do período de incubação foi ligeiramente maior do que nos solos PV1 e LV3. As atividades microbianas avaliadas anteriormente mostraram que estes solos possuem uma capacidade maior de metabolizar o glifosato presente e com isso apresentarem uma maior degradação do herbicida para o seu principal metabólito.

O aparecimento do metabólito está relacionado com a degradação do glifosato pelos microrganismos do solo. O AMPA também é degradado pelos microrganismos, e provavelmente teria a sua concentração diminuída caso fosse monitorado por um período superior ao determinado neste experimento. Veiga et al. (2001) avaliaram a dinâmica do glifosato e AMPA e observaram que a concentração do herbicida decrescia enquanto a do seu metabólito aumentava nas primeiras semanas do experimento, após esse período inicial a concentração do AMPA decrescia devido a sua degradação. 
Tabela 11. Quantidade de glifosato e AMPA $\left(\mathrm{mg} \cdot \mathrm{kg}^{-1}\right)$ nas amostras dos solos PV1, PV2, LV3 e LV4. Aos 0, 8, 16 e 32 dias de incubação, no escuro. Média de três repetições ( \pm desvio padrão).

\begin{tabular}{ccccc}
\hline Solos & PV1 & PV2 & LV3 & LV4 \\
\hline Glifosato & $2,116( \pm 0,03)$ & $2,370( \pm 0,10)$ & $1,535( \pm 0,01)$ & $1,530( \pm 0,01)$ \\
AMPA & nd & $0,18( \pm 0,47)$ & nd & nd \\
& & & \\
dias & & \\
Glifosato & $0,860( \pm 0,03)$ & $0,941( \pm 0,10)$ & $0,487( \pm 0,01)$ & $0,677( \pm 0,01)$ \\
AMPA & $0,372( \pm 0,6)$ & $0,301( \pm 0,47)$ & $0,297( \pm 0,6)$ & $0,360( \pm 0,5)$ \\
& & 16 dias & \\
Glifosato & $0,582( \pm 0,035)$ & $0,460( \pm 0,10)$ & $0,370( \pm 0,012)$ & $0,578( \pm 0,011)$ \\
AMPA & $0,461( \pm 0,64)$ & $0,622( \pm 0,47)$ & $0,374( \pm 0,60)$ & $0,479( \pm 0,53)$ \\
& & 32 dias & & \\
Glifosato & $0,148( \pm 0,035)$ & $0,139( \pm 0,10)$ & $0,202( \pm 0,012)$ & $0,461( \pm 0,011)$ \\
AMPA & $0,504( \pm 0,64)$ & $0,788( \pm 0,47)$ & $0,446( \pm 0,60)$ & $0,677( \pm 0,53)$ \\
\hline
\end{tabular}

A partir das curvas de degradação, mostradas nos gráficos das Figuras 15, 16, 17 e 18, obtêm-se as equações que definem a meia-vida do glifosato para estes solos avaliados. A meia-vida do glifosato foi de 9, 8, 12 e 22 dias para os solos PV1, PV2, LV3 e LV4, respectivamente. A meia-vida menor encontrada para os solos PV1 e PV2 pode ser devido a maior disponibilidade do glifosato para os biodegradação, já que estes solos não possuem altos teores de argila e provavelmente não adsorvem fortemente o herbicida. Em 
relação aos solos LV3 e LV4, que possuem maiores teores de argila, provavelmente o glifosato pode estar mais adsorvido a essas partículas dificultando o ataque microbiano e consequentemente aumentando sua meiavida no ambiente. Segundo Carlisle \& Trevors (1978), a meia-vida do glifosato no ambiente pode variar de pouco menos que uma semana até anos, dependendo do tipo de solo e sua atividade microbiana.

Observa-se que o solo LV4, com histórico de 11 anos de aplicação de glifosato, apresentou uma meia-vida muito maior, se comparado com o solo LV3, sem histórico de aplicação. O sistema de plantio direto proporciona uma maior disponibilidade de nutrientes para os microrganismos ocasionando um incremento na atividade microbiana e aumentando a meia-vida do glifosato. Esta hipótese pode ser comprovada pela maior atividade microbiana, mensurada pela evolução do $\mathrm{CO}_{2}$, encontrada neste solo (Figura 3). 


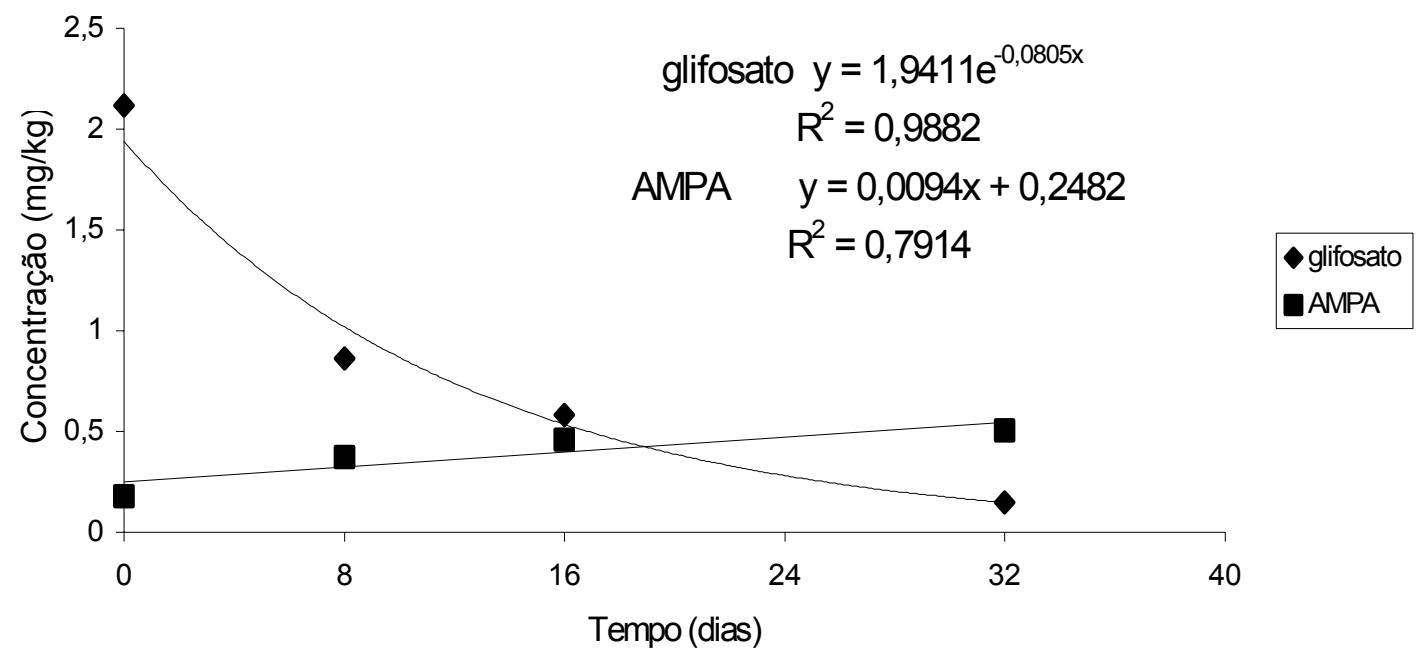

Figura 15 - Gráfico de concentrações de glifosato e AMPA, na amostra de solo PV1, durante o período de incubação.

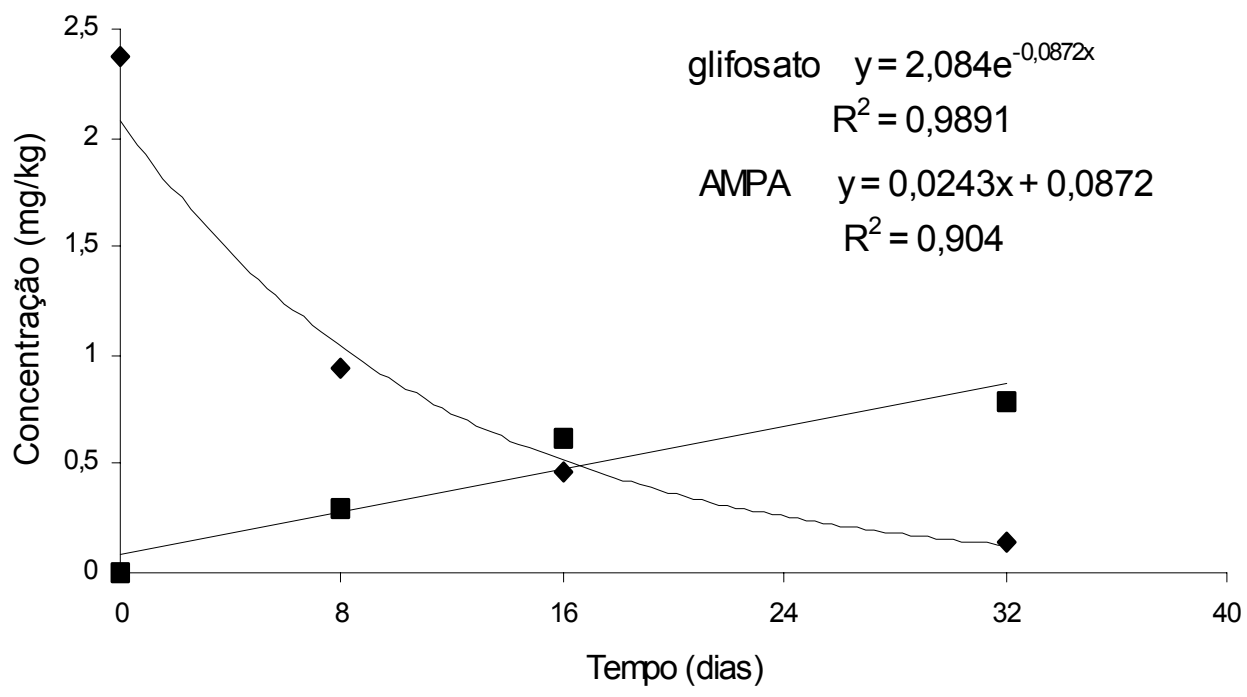

Figura 16 - Gráfico de concentrações de glifosato e AMPA, na amostra de solo PV2, durante o período de incubação. 


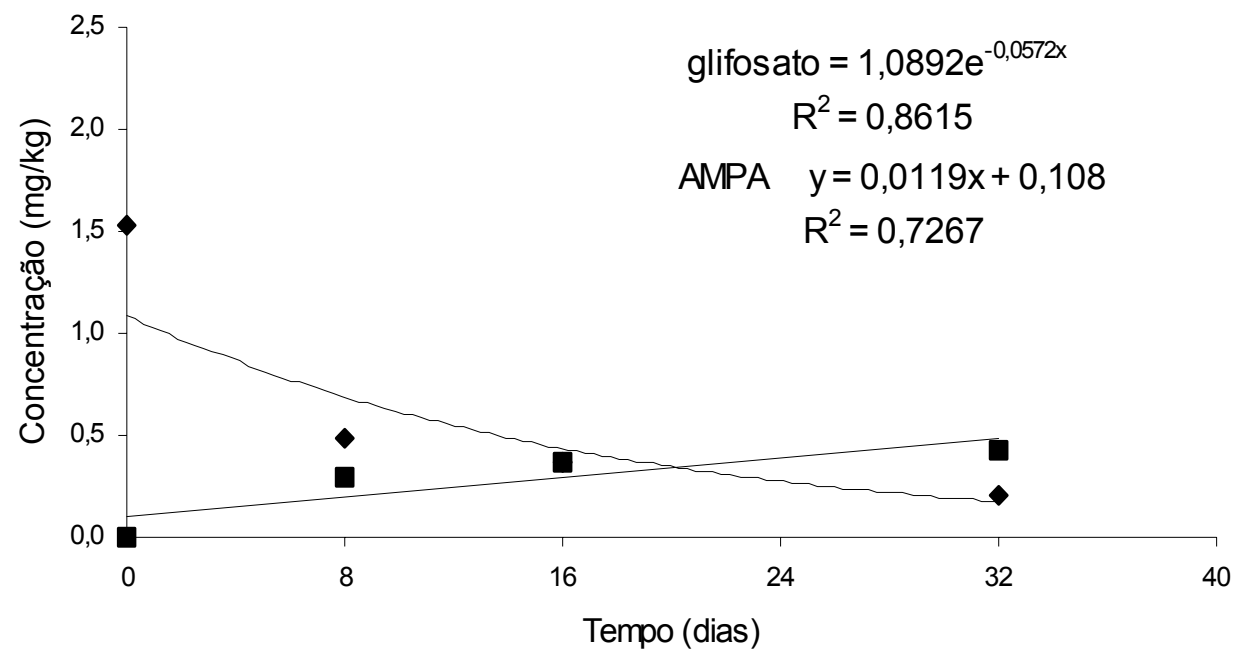

Figura 17 - Gráfico de concentrações de glifosato e AMPA, na amostra de solo LV3, durante o período de incubação.

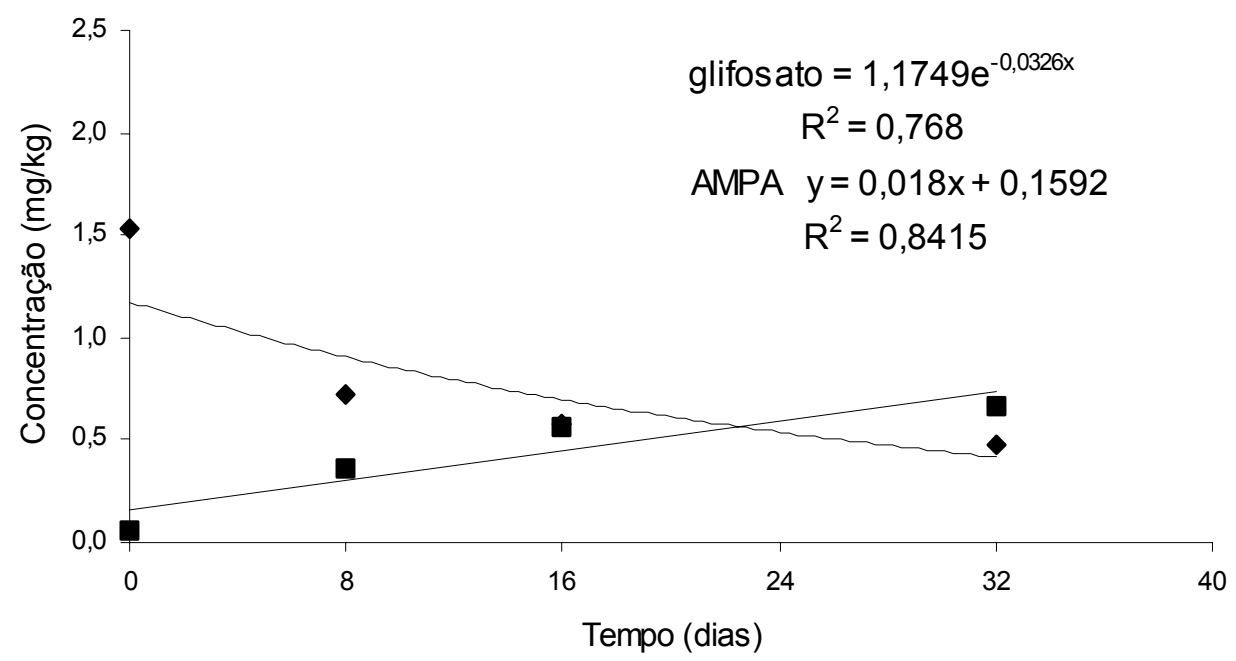

Figura 18 - Gráfico de concentrações de glifosato e AMPA, na amostra de solo LV4, durante o período de incubação. 


\section{CONCLUSÕES}

- A biodegradação de glifosato foi maior nas amostras dos solos, com histórico de aplicação, mostrando ocorrer adaptação da microbiota para utilização do herbicida.

- Na presença de glifosato o número de fungos aumentou durante o período de incubação, mostrando ser este o grupo predominante e provável degradador do composto. Os actinomicetos variaram conforme o tratamento e as bactérias permaneceram em número constante durante o período de incubação.

- Os resultados do desaparecimento de glifosato e o aparecimento do metabólito ácido aminometil fosfônico (AMPA), determinados por CLAE, são proporcionais aos encontrados para respiração e atividade microbiana.

- A meia-vida de glifosato avaliada foi de 9 dias e 8 dias, para as amostras dos solos podzólicos vermelho-amarelo (PV1 e PV2) e de 12 dias e 22 dias, para as amostras dos solos latossolos vermelho (LV3 e LV4), respectivamente.

- O método de extração utilizado mostra ser bastante eficiente, com recuperação acima de $70 \%$ do glifosato e AMPA nas amostras analisadas. 


\section{REFERENCIAS BIBLIOGRÁFICAS}

ALEXANDER, M. Introduction to soil microbiology. 2.ed. New York: John Wiley \& Sons, 1977. 467p.

ALEXANDER, M. Biodegradation of chemicals of environmental concern. Science, v.211, p.132-138, 1981.

ALFERNESS, P.L.; IWATA, Y. Determination of glyphosate and (aminomethyl) phosphonil acid in soil, plant and animal matrice, and water by capillary gas chromatography with mass-selective detection. Journal of Agricultural and Food Chemistry, v.42, n.12, p.2751-2759, 1994.

ALMEIDA, F.S. Guia de herbicidas: recomendações para o uso adequado em plantio direto e convencional. Londrina: IAPAR, 1985. 482p.

ANDERSON, J.P.E. Pesticides effects on non-target soil microrganisms. In: HILL, I.R.; WRIGHT, S.J.E. (Ed.). Pesticides microbiology. New York: Academic Press, 1978. p.611-628.

ARMAS, E.D. Comportamento de glifosate em solos de várzea sob sistema plantio direto e a eletroforese capilar na análise de resíduos. Piracicaba, 2002. 102p. Dissertação (Mestrado) - Centro de Energia Nuclear na Agricultura, Universidade de São Paulo.

AUBIN, A.J.; SMITH, A.E. Extraction of $\left[{ }^{14} \mathrm{C}\right]$ Glyphosate from Saskatchewan soils. Journal of Agricultural and Food Chemistry, v.40, n.7, p.11631165, 1992.

BARTHA, R.; PRAMER, D. Features of a flask and method for measuring the persistence and biological effects of pesticides in soil. Soil Science, v.100, n.1, p.68-70, 1965. 
BEIGEL, C.; CHARNAY, M.P.; BARRIUSO, E. Degradation of formulated and unformulated triticonazole fungicide in soil: effect of application rate. Soil Biology \& Biochemistry, v.31, n.4, p.525-534, 1999.

BJORNLUND, L.; EKELUND, F.; CHRISTENSEN, S. et al. Interactions between saprotrophic fungi, bacteria and protozoa on decomposing wheat roots in soil influenced by the fungicide fenpropimorph (Corbel ${ }^{\mathrm{TM}}$ ): a field study. Soil Biolgy \& Biochemistry, v.32, n.7, p.967-975, 2000.

BOLLAG, J.M.; LIU, S.Y. Biological transformation processes of pesticides. In: CHENG, H.H. (Ed.) Pesticides in the soil environment: processes, impacts, and modeling. Madison: Soil Science Society of American, 1990. p.169-211.

BORJESSON, E.; TORSTENSSON, L. New methods for determination of glyphosate and (aminomethyl) phosphonic acid in water and soil. Journal of Chromatography A, v.886, p.207-216, 2000.

BROMILOW, R.H.; EVANS, A.A.; NICHOLLS, P.H. et al. The effect on soil fertility of repeated applications of pesticides over 20 years. Pesticides Science, v.48, n.1, p.63-72, 1996.

BUJACZ, B.; WIECZOREK, P.; KRZYSKO-LUPICKA, T. et al. Organophosphate utilization by the wild-type strain of Penicillium notatum. Applied and Environmental Microbiology, v.61, n.8, p.2905-2910, 1995.

BUSSE, M.D.; RATCLIFF, A.W.; SHESTAK, C.J. et al. Glyphosate toxicity and the effects of long-term vegetation control on soil microbial communities. Soil Biology \& Biochemistry, v.33, n.12-13, p.1777-1789, 2000.

CARLISLE, S.M.; TREVORS, J.T. Glyphosate in the environment. Water, Air Soil Pollution, v.39, p.409-420, 1988.

CHEAH, U.; KIRKWOOD R.C.; LUM K. Degradation of commonly used pesticides in Malaysian agricultural soils. Journal of Agricultural and Food Chemistry, v.46, n.3, p.1217-1223, 1998. 
DAS, A.C.; MUKHERJEE, D. Soil application of insecticides influences microorganisms and plant nutrients. Applied Soil Ecology, v.14, n.1, p.5562, 2000.

DICK, R.E.; QUINN, J.P. Glyphosate-degrading isolates from environmental samples: occurrence and pathways of degradation. Applied Microbiology Biotechnology, v.43, n.3, p.545-550, 1995.

DORES, E.F.G.C.; DE-LAMONICA-FREIRE, E.M. Contaminação do ambiente aquático por pesticidas. Estudo de caso: águas usadas para consumo humano em Primavera do Leste, Mato Grosso: análise preliminar. Química Nova, v.24, n.1, p.27-36, 2001.

EBERBACH, P.L. Applying non-steady-state compartmental analysis to investigate the simultaneous degradation of soluble and sorbed glyphosate (N-Phosphonomethyl) glycine) in four soils. Pesticide Science, v.52, n.3, p.229-240, 1998.

EBERBACH, P.L. Influence of incubation temperature on the behavior of triethylamine-extractable Glyphosate (N-Phosphonometylglycine) in four soils. Journal of Agricultural and Food Chemistry, v.47, n.6, p.24592467, 1999.

EBERBACH, P.L; DOUGLAS, L.A. Method for the determination of glyphosate and (aminomethyl) phosphonic acid in soil using electron capture gas chromatography. Journal of Agricultural and Food Chemistry, v.39, n.5, p.1776-1780, 1991.

FOMSGAARD, I.S. Modelling the mineralization kinetics for low concentrations of pesticides in surface and subsurface soil. Ecological Modelling, v.102, p.175-208, 1997.

FORLANI, G.; MANGIACALLI, A.; NIELSEN, E. et al. Degradation of the phosphonate herbicide glyphosate in soil: evidence for a possible involvement of unculturable microorganism. Soil Biology and Biochemistry, v.31, n.7, p.991-997, 1999. 
GHINI, R.; LIGO, M.A.V.; HERMES, L.C. Efeito de herbicidas na biomassa microbiana de solos de arroz irrigado. Revista Ecossistema, v.22, p.97101, 1997.

GLASS, R.L. Liquid chromatography determination of glyphosate in fortified soil and water samples. Journal of Agricultural and Food Chemistry, v.31, n.2, p.280-282, 1983.

GROSSBARD, E.; ATKINSON, D. The herbicide glyphosate. London: Butterworths Co., 1985. 490p.

HANEY, R. L.; SENSEMAN, S. A.; HONS, E. M. et al. Effect of glyphosate on soil microbial activity and biomass. Weed Science, v.48, n.1, p.89-93, 2000.

HART, M.R. ; BROOKES, P.C. Soil microbial biomass and mineralisation of soil organic matter after 19 years of cumulative field application of pesticides. Soil Biology and Biochemistry, v.28, n.12, p.1641-1649, 1996.

HEINONEN-TANSKI, $H$. The effect of temperature and liming on the degradation of glyphosate in two artic forest soils. Soil Biology \& Biochemistry, v.21, n.2, p.313-317, 1989.

INSTITUTO BRASILEIRO DE MEIO AMBIENTE E RECURSOS RENOVÁVEIS. Manual de testes para avaliação da ecotoxicidade de agentes químicos. 2.ed. Brasília: IBAMA, 1990. 351p.

JAHNEL, M.C.; CARDOSO, E.J.B.N.; DIAS, C.T.S. Determinação do número mais provável de microrganismos do solo pelo método de plaqueamento por gotas. Revista Brasileira de Ciência do Solo, v.23, n.3, p-553-559, 1999.

JONGE, H. ; JONGE, L.W. Influence of $\mathrm{pH}$ and solution composition on the sorption of glyphosate and prochloraz to a sandy loam soil. Chemosphere, v.39, n.5, p.753-763, 1999.

KATAOKA, H.; RYU, S.; SAKIYAMA, N. et al. Simple and rapid determination of the herbicide glyphosate and glufosinate in river water, soil and carrot sample by gas chromatography with flame photometric detection. Journal of Chromatography A, v.726, p.253-258, 1996. 
KERTESZ, M.A.; COOK, A.M.; LEISINGER, T. Microbial metabolism of sulfurand phosphorus-containing xenobiotics. FEMS Microbiology Review, v.15, n.2-3, p.195-215, 1994.

KNUUTTILA, P.; KNUUTTILA, $\mathrm{H}$. The crystal and molecular structure of $\mathrm{N}$ (phosphonomethyl)-glycine (glyphosate). Acta Chemical Scandinavia B, v.33, p.623-626, 1979.

KRZYSKO-LUPICKA, T.; ORLIK, A. The use of glyphosate as the sole source of phosphorus or carbon for the selection of soil-borne fungal strains capable to degrade this herbicide. Chemosphere, v.34, n.12, p.2601-2605, 1997.

LEHR, S.; SCHEUNERT, I.; BEESE, F. Mineralization of free and cell-wall-bond isoproturon in soils in relation to soil microbial parameters. Soil Biology \& Biochemistry, v.28, n.1, p.1-8, 1996.

LERBS, W.; STOCK, M.; PANTHIER, B. Physiological aspects of glyphosate degradation in Alcaligens spec strain GL. Archives Microbiology, v.153, n.2, p.146-150, 1990.

LIU, C.M.; McLEAN, P.A.; SOOKDEO, C.C. et al. Degradation of the herbicide glyphosate by members of the family Rhizobiaceae. Applied and Environmental Microbiology, v.57, n.6, p1799-1804, 1991.

MCBRIDE, M.B. Environmental chemistry of soils. Oxford: Oxford University Press, 1994. 545p.

MEGHARAJ, M.; SINGLETON, I.; KOOKANA, R. et al. Persistence and effects of fenamiphos on native algal population and enzymatic activities in soil. Soil Biology \& Biochemistry, v.31, n.11, p.1549-1553, 1999.

MILLES, C.J.; MOYE, H.A. Extraction of glyphosate herbicide from soil and clay minerals and determination of residues in soils. Journal of Agricultural and Food Chemistry, v.36, n.3, p.486-491, 1988.

MONSANTO. Manual técnico de produtos. São Paulo: Monsanto, 1990. 31p. MONTEIRO, R.T.R. Biodegradação de herbicidas. In: Workshop Sobre Biodegradação. Jaguariúna: EMBRAPA Meio Ambiente, 1996. p.120-128. 
MONTEIRO, R.T.R. Biodegradação de pesticidas em solos brasileiros. In: MELO, I.S.; SOUZA, C.M.M.; SCRAMIN, S.; SPESSOTO, A. (Ed.). Biodegradação. Jaguariúna: EMBRAPA Meio Ambiente, 2001. p.1-14.

MORILLO, E.; UNDABEYTIA,T.; MAQUEDA, C. et al. Glyphosate adsorption on soils of different characteristics: Influence of copper addition. Chemosphere, v.40, n.1, p.103-107, 2000.

MOSHIER, L.J.; PENNER, D. Factors influencing microbial degradation of ${ }^{14} \mathrm{C}$ glyphosate to ${ }^{14} \mathrm{CO}_{2}$ in soil. Weed Science, v.26, n.6, p.686-691, 1978.

MOYE, H.A.; DEYRUP, C.L. A single single-step derivatization method for the gas chromatography analysis of the herbicide glyphosate and its metabolite. Journal of Agricultural and Food Chemistry, v.33, n.2, p.192-195, 1984.

MUNIER-LAMY, C.; BORDE, O. Effect of a triazole fungicide on the cellulose decomposition by the soil microflora. Chemosphere, v.41, n.7, p.10291035, 2000.

MUSUMECI, M.R. Defensivos agrícolas e sua interação com a microbiota do solo. In: CARDOSO, E.J.B.N.; TSAI, S.M.; NEVES, M.C.P. (Ed.). Microbiologia do solo. 1.ed. Campinas: Sociedade Brasileira de Ciência do Solo, 1992. p.341-356.

NOMURA, N.S.; HILTON, H.W. The adsorption and degradation of glyphosate in five Hawaiian sugarcane soils. Weed Research, v.17, n.2, p.113-121, 1977.

OBOJSKA, A.; LEJCZAK, B.; KUBRAK, M. Degradation of phosphonates by streptomycetes isolates. Applied Microbiology Biotechnology, v.51, n.6, p.872-876, 1999.

OLSON, B.M.; LINDWALL, C.W. Soil microbial acticity under chemical follow conditions: effects of 2,4-D and glyphosate. Soil Biology \& Biochemistry, v.23, n.4, p.1071-1075, 1991.

OTTO, S.; RIELLO, L.; DURING, R.A. et al. Herbicides dissipation and dynamics modelling in three different tillage system. Chemosphere, v.34, n.1, p.163-178, 1997. 
PERRIN-GANIER, C.; SCHIAVON, M.; PORTAL, J.M. et al. Degradation de pisoproturon et disponibilité des residus dons les sol. Weed Research, v.35, n.2, p.257-263, 1995.

PICCOLO, A; CELANO, G.; CONTE, P. Adsorption of glyphosate by humic substances. Journal of Agricultural and Food Chemistry, v.44, n.8, p.2442-2446, 1996.

PRADO, A.G.S.; AIROLDI, C. Effect of the pesticide 2,4-D on microbial activity on the soil monitored by microcalorimetry. Thermochimica Acta, v.349, n.1, p.17-22, 2000.

RAO, P.S.C.; BELLIN, C.A.; BRUSSEAU, M.L. Coupling biodegradation of organic chemicals to sorption and transport in soil and aquifers: paradigms and paradoxes. In: LINN, D.M.; CARSKI, T.H.; BRUSSEAU, M.L. et al. (Ed.). Sorption and degradation of pesticides and organic chemicals in soil. Madison: Wisconsin, 1993. p.1-26.

RATH, A.K.; RAMAKRISHNAN, B. RATH, A.K. et al. Effect of pesticides on microbial biomass of flooded soil. Chemosphere, v.37, n.4, p.661-671, 1998.

ROBERTSON, B. K.; ALEXANDER, M. Growth-linked and cometabolic biodegradation: possible reason for ocurrence or absence of accelerated pesticide biodegradation. Pesticide Science, v.41, n.4, p.311-318, 1994.

ROSLYCKY, E.B. Glyphosate and the response of the soil microbiota. Soil Biology \& Biochemistry, v.14, n.1, p.87-92, 1982

ROY, D.N.; KONAR, S.K. Development of an analytical method for the determination of glyphosate and (aminomethyl) phosphonic acid residues in soil by nitrogen-selective gas chromatography. Journal of Agricultural and Food Chemistry, v.37, n.2, p.441-443, 1989.

RUEPPEL, M. L.; BRIGHTWELL, B. B.; SCHAEFER, J. et al. Metabolism and degradation of glyphosate in soil and water. Journal of Agricultural and Food Chemistry, v.25, n.3, p.517-528, 1977. 
SANCHO, J.V.; HIDALGO, C.; HERNANDEZ, F. et al. Rapid determination of glyphosate residues and its main metabolite AMPA in soil samples by liquid chromatography. International Journal of Environmental Analitycal Chemistry, v.62, n.1, p.53-63, 1996.

SANINO, F.; FILAZZOLA, M.T.; VIOLANTE, A. et al. Fate of herbicides influenced by biotic and abiotic interactions. Chemosphere, v.39, n.2, p.333-341, 1999.

SCHNÜRER, J.; ROSSWALL, T. Fluorescein diacetate hydrolysis as a measure of total microbial activity in soil an litter. Applied Environmental Microbiology, v.43, n.5, p.1256-1261, 1982.

SCHUSTER, R.; GRATZFELD-HÜSGEN, A. A comparison of pre- and post column sample treatment for the analysis of glyphosate. Waldbronn: Agilent Technologies, 1992. 7p.

SOMASSUNDARAM, L.; COATS, J.R. Influence of pesticides metabolites on the development of enhanced biodegradation. In: Enhanced biodegradation of pesticides in the environment. Washington: Americam Chemical Society, 1990. p.128-140.

SOUZA, A.P. Atividade de oxyfluorfen, 2,4-D e glifosate, em solos de diferentes texturas na presença e na ausência de composto orgânico. Viçosa, 1994. 71p. Dissertação (Mestrado) - Universidade Federal de Viçosa.

SOUZA, A. P. Movimento e degradação do glyphosate e do imazapyr em solos de diferentes texturas e composição química. Viçosa, 1998. 95p. Tese (Doutorado) - Universidade Federal de Viçosa.

SOUZA, A.P.; PRATES, H.T.; FERREIRA, F.A. et al. Lixiviação do glyphosate e do imazapyr em solos com diferentes texturas e composição química. II: Método analítico. Planta Daninha, v.17, n.2, p.245-262, 1999a.

SOUZA, A.P.; FERREIRA, F.A.; SILVA, A.A.. et al. Respiração microbiana do solo sob doses de glyphosate e de imazapyr. Planta Daninha, v.17, n.3, p.387-398, 1999b. 
SPANN, K.P.; HARGREAVES, P.A. The determination of glyphosate in soils with moderate to high clay content. Pesticide Science, v.40, n.1, p.41-48, 1994.

SPRANKLE, P.; MEGGITT, W.F.; PENNER D. Adsorption, mobility, and microbial degradation of glyphosate in the soil. Weed Science, v.23, n.3, p.229-234, 1975.

STALIKAS, C.D.; KONIDARI, C.N. Analytical methods to determine phosphonic and amino acid group-containing pesticides. Journal of Chromatography A, v.907, n.1-2, p.1-19, 2001.

STRATTON, G.W.; STEWART, K.E. Glyphosate effects on microbial biomass in a coniferous forest soil. Environmental Toxicology and Water Quality, v.17, n.3, p.223-236, 1992.

SUETT, D.L.; FOURNIER, J.C.; PAPADOPOULOU-MOURKIDOU, E. et al. Accelerated degradation: the european dimension. Soil Biology \& Biochemistry, v.28, n.12, p.1741-1748, 1996.

TAIWO, L.B.; OSO, B.A. The influence of some pesticides on soil microbial flora in relation to changes in nutrient level, rock phosphate solubilization and $\mathrm{P}$ release under laboratory conditions. Agriculture, Ecosystems and Environment, v.65, n.1, p.59-68, 1997.

TORSTENSSON, N.T.L. Behaviour of glyphosate in soils and its degradation. In: GROSSBARD, E.; ATKINSON, D. (Ed.). The herbicide glyphosate. London: Butterworths Co., 1985. p.137-150.

TORSTENSSON, N.T.L.; AAMISEPP, A. Detoxification of glyphosate in soil. Weed Research, v.17, n.2, p.209-212, 1977.

TORSTENSSON, N.T.L.; LUNDGREN, L.N.; STENSTROM, J. Influence of climate and edaphic factors on persistence of glyphosate and 2,4-D in forest soils. Ecotoxicology Environment Safety, v.18, n.3, p.230-239, 1989.

VEIGA, F.; ZAPATA, M.L.; FERNANDEZ, M. et al. Dynamics of glyphosate and aminomethylphosphonic acid in a forest soil in Galicia, noth-west Spain. The Science of the Total Environment, v.271, n.1, p.135-144, 2001. 
WIREN-LEHR, S.; KOMOBA, D.; GLABGEN, W.E. et al. Mineralization of $\left[{ }^{14} \mathrm{C}\right]$ glyphosate and its plant-associated residues in arable soils originating from different farming systems. Pesticide Science, v.51, n.4, p.436-442, 1997.

WARDLE, D. A.; PARKINSON, D. Effects of three herbicides on soil microbial biomass and activity. Plant and Soil, v.122, n.1, p.21-28, 1990a.

WARDLE, D. A.; PARKINSON, D. Influence of the herbicide glyphosate on soil microbial community structure. Plant and Soil, v.122, n.1, p.29-37, 1990b.

WILLIAMS, G.M.; KROES, R.; MUNRO, I.C. Safety evaluation and risk assessment of the herbicide Roundup and its active ingredient, glyphosate, for humans. Regulatory Toxicology and Pharmacology, v.31, n.1, p.117$165,2000$.

YOUNG, J.C.; KHAN, S.V.; MARRIAGE, P.B. Fluorescence detection and determination of glyphosate via its $\mathrm{N}$-nitroso derivative by thin-layer chromatography. Journal of Agricultural and Food Chemistry, v.25, n.4, p.918-923, 1977.

ZABLOTOWICZ, R.M.; LOCKE, M.A.; SMEDA, R.J. Degradation of 2,4-D and fluometuron in cover crop residues. Chemosphere, v.37, n.1, p.87-101, 1998.

ZARANYIKA, M.F.; NYANDORO, M.G. Degradation of glyphosate in the aquatic environment: an enzymatic kinetic model that takes into account microbial degradation of both free and colloidal (or sediment) particle adsorbed glyphosate. Journal of Agricultural and Food Chemistry, v.41, n.5, p.838842, 1993. 